\title{
New Perspectives on Abiotic Organic Synthesis and Processing during Hydrothermal Alteration of the Oceanic Lithosphere
}

\author{
MURIEL ANDREANI AND BÉNÉDICTE MÉNEZ
}

\subsection{Introduction}

The main known organic compounds on Earth are biologically derived, whether they are direct products of biological activity or the result of thermal degradation of bio-derived material. While the synthesis of organic compounds from inorganic reactants is a common process in the chemical industry, it remains an unverified component of the deep carbon cycle on Earth and possibly on other planetary bodies. Abiotic organic synthesis is central to life emergence and sustainability, and possibly to "geo-inspired" resources. Intensive efforts are still needed to unravel the possible forms, sources, quantities, and formation mechanisms of abiotic carbon compounds under geologically relevant conditions. An improved knowledge of their processing within the lithosphere is also mandatory to better quantify their impact on biogeochemical cycles and their contribution to $\mathrm{C}$ fluxes between Earth's external and internal envelops. Their presence in fluids and rocks may also affect the kinetics of fluid-silicate reactions and the fates of other elements, particularly the redox-sensitive ones (e.g. transition metals, S).

Abiotic organic compounds in the lithosphere can have two main origins: either rising from a deep volcanic source in the mantle or formed in situ in the upper lithosphere during hydrothermal processes from mantellic or seawater inorganic carbon compounds (see Refs. 1 and 2 for reviews). In the present chapter, we focus on lithospheric hydrothermal processes that include late magmatic stages and fluid-rock reactions.

In fluids, natural occurrences of recognized abiotic organic volatiles of hydrothermal origin include methane $\left(\mathrm{CH}_{4}\right)$, short-chain alkanes, and small organic acids. They have mainly been observed in geothermal systems or continental seepages within ophiolites and Precambrian shields ${ }^{3}$ and at hydrothermal vents near mid-ocean ridges ${ }^{4}$ and subduction forearcs. ${ }^{5}$ Hence, they are not necessarily associated with deep active volcanism, and they attest to the contribution of lithospheric hydrothermal processes to abiotic organic synthesis. In most cases, these occurrences of organic volatiles are associated with high concentrations of $\mathrm{H}_{2}$ reached by reduction of water during aqueous alteration of ferrous iron-bearing minerals. The latter are particularly abundant in mantle and olivine-rich lithologies whose alteration process is known as serpentinization. 
$\mathrm{CH}_{4}$ and short-chain hydrocarbons have attracted scientific attention over recent decades, and different reactions have been proposed to explain their possible abiotic formation. ${ }^{1,3}$ The ones occurring in the oceanic lithosphere include re-speciation and high-temperature $(\mathrm{T})$ reactions $\left(>400-500^{\circ} \mathrm{C}\right)$ of magmatic $\mathrm{C}-\mathrm{O}-\mathrm{H}$ fluids during cooling, carbonate decomposition to $\mathrm{CH}_{4}\left(<800^{\circ} \mathrm{C}\right)$, and inorganic carbon reduction by $\mathrm{H}_{2}$ at lower $\mathrm{T}\left(<400-500^{\circ} \mathrm{C}\right)$. The latter has been the most investigated pathway and may occur through Fischer-Tropsch-type (FTT) reactions under gaseous or aqueous conditions. However, the exact mechanism and the nature of potential metal catalysts are still debated (see reviews in Refs. 1 and 6). Up to now, experimental results have converged toward kinetic inhibition of $\mathrm{CH}_{4}$ formation at low $\mathrm{T}\left(<300-400^{\circ} \mathrm{C}\right)$ according to the low methane yield achieved in most experiments (see Section 15.3.1). This is in agreement with recent work putting forward a dominant deep source for $\mathrm{CH}_{4}$ venting at mid-ocean ridges. ${ }^{7,8}$ This deep $\mathrm{CH}_{4}$ may result from the entrapment and re-speciation at high $\mathrm{T}\left(>400^{\circ} \mathrm{C}\right)$ of mantle-derived $\mathrm{CO}_{2}$ within fluid inclusions or vesicles in magmatic rocks, ${ }^{9,10}$ the fluids being later released during hydrothermal alteration of oceanic rocks. Conversely, no consensus has yet emerged to explain the origin of $\mathrm{CH}_{4}$ seepages observed in continental settings where fluid-rock reactions occur at even lower $\mathrm{T}\left(<100^{\circ} \mathrm{C}\right)$. Such settings may offer favorable environments for gas-phase reactions that are more efficiently catalyzed than aqueous ones. ${ }^{11}$ However, most of these assumptions are based on $\mathrm{CH}_{4}$ carbon isotopic signatures that can be highly similar to those produced by microbial methanogenesis under alkaline conditions at high levels of dissolved inorganic carbon. ${ }^{12,13}$

Among organic acids, formate is the only one so far recognized as being of possible abiotic origin in nature, resulting from the equilibration in aqueous solution of $\mathrm{CO}_{2}$ or carbonate ions and $\mathrm{H}_{2}$ under neutral to alkaline conditions. ${ }^{14-16}$ A variety of other (e.g. methanethiol, amino acids) and heavier (aliphatic and aromatic hydrocarbons, organic acids) organic compounds were also observed in hydrothermal vent fluids and chimneys, but they are often considered as biologically derived. ${ }^{16-24}$ Should abiotic synthesis of such compounds occur, they are likely to be too diluted in hydrothermal fluids to be distinguished from background biological contributions. ${ }^{24}$

Bulk analyses of hard rocks from the oceanic lithosphere describe up to $1500 \mathrm{ppm}$ of total organic carbon (TOC) in serpentinized abyssal peridotites. ${ }^{25-28}$ If some are present as volatile organic compounds adsorbed on minerals, a fraction is possibly present as solid carbonaceous matter (CM). The nature, diversity, and origin of such organic phases remain poorly constrained, and one cannot preclude a biological contribution to their formation $^{29-31}$ and a thermogenic origin as for kerogens. ${ }^{30,31}$ Part of this controversy is due to the fact that occurrences were found in potentially colonized environments and that spectroscopic, chemical, and isotopic evidence lacks unequivocal criteria to discriminate between abiotic and biotic origins. In addition, most of the conditions and reactions leading abiotically to carbonaceous compounds are mostly unknown, including their relationship with methane. The experimental difficulty to produce sufficient $\mathrm{CH}_{4}$ during hydrothermal synthesis compared to what is observed in nature suggests alternative organic products 
being preferentially formed and leaves the door open to the existence of metastable compounds in the shallow lithosphere. ${ }^{32-35}$

All of these data force one to consider new paradigms for abiotic organic synthesis in hydrothermal settings, not being $\mathrm{CH}_{4}$ centered, but rather including the potential formation of organic carbon compounds with intermediate oxidation states, possibly mediated by rock-forming minerals. In this chapter, we discuss natural occurrences of carbonaceous compounds within the hard rocks of the oceanic lithosphere or analogs to complement the numerous studies and reviews focused on organic compounds in fluids discharged at oceanic hydrothermal vents or continental seeps (e.g. Refs. 3 and 20). Data on natural rocks affected by low-T $\left(<400^{\circ} \mathrm{C}\right)$ and high-T $\left(>400^{\circ} \mathrm{C}\right)$ hydrothermal reactions are compared to the most pertinent experimental and theoretical data currently available. Some resulting assertions remain hypothetical but provide new schemes for considering and investigating organic synthesis in lithospheric hydrothermal environments.

\subsection{Carbonaceous Matter in Hydrothermally Altered, Mantle-Derived Rocks}

Accumulations of $\mathrm{CM}$ can be found from the Proterozoic to the present time in volcanic and igneous rocks from a diversity of geodynamic contexts, including spreading zones, oceanic hot spots, island arcs, and continental rifts. ${ }^{36,37}$ We focus here on the organic carbon suspected to be nonbiological based on investigations of the most favorable rocky environments for abiotic organic synthesis (i.e. during hydrothermalism affecting mantlederived rocks).

\subsubsection{Bulk Rock Investigations}

The first mention of the presence of CM in mafic and ultramafic rocks came from the vast Russian literature published since the 1950s. At that time, the so-called Russian-Ukrainian School had spent significant effort in exploring hydrocarbons in mafic and ultramafic rocks to support a deep mantle origin hypothesis for hydrocarbons deposits. We refer to Sephton and Hazen $^{2}$ for a historical perspective and an inventory of achievements in this field. Although a large part of these studies remains untranslated, a review of the occurrences of putatively abiotic condensed naphtides showed a large diversity of compounds associated with volcanic and igneous rocks in a wide range of geodynamic contexts. ${ }^{37}$ These compounds include aromatic and aliphatic hydrocarbons and their N-, O-, and S-bearing derivatives. Notably, they mainly occur in mafic and ultramafic rocks. The first study targeting oceanic rocks has focused on the Rainbow $\left(36^{\circ} 14^{\prime} \mathrm{N}\right)$ and Logatchev $\left(14^{\circ} 45^{\prime} \mathrm{N}\right)$ hydrothermal fields (Mid-Atlantic Ridge (MAR)). ${ }^{38}$ In addition to the presence of lowmolecular-weight alkanes and isoalkanes, this study reported the presence of CM in serpentinized rocks, in metalliferous sediments, and in secondary Fe-Ni sulfides. The $\mathrm{Fe}-\mathrm{Ni}$ sulfides presented the highest concentrations and the broadest diversity of viscous and solid organic compounds depicted as resinous bitumen. Notably, a compositional 
Table 15.1 Organic minerals related to hydrothermal alteration in mafic and ultramafic rocks. ${ }^{38,47}$ With the exception of evenkite, which is classified as an alkane mineral, all are PAH minerals (adapted from Echigo and Kimata ${ }^{39}$ ).

\begin{tabular}{|c|c|c|c|}
\hline Mineral & Chemical formula & Chemical nomenclature & Refs. \\
\hline Karpatite & $\mathrm{C}_{24} \mathrm{H}_{12}$ & Coronene & 48 \\
\hline Idrialite & $\mathrm{C}_{22} \mathrm{H}_{14}$ & Picene & 49 \\
\hline Kratochvilite & $\begin{array}{l}\left(\mathrm{C}_{6} \mathrm{H}_{4}\right) \\
\mathrm{CH}_{2}\left(\mathrm{C}_{6} \mathrm{H}_{4}\right)\end{array}$ & Fluorene & 50 \\
\hline Simonellite & $\mathrm{C}_{19} \mathrm{H}_{24}$ & $\begin{array}{l}\text { 1,1-Dimethyl-7-isopropyl-1,2,3,4-tetrahydro- } \\
\text { phenanthrene }\end{array}$ & 51 \\
\hline Evenkite & $\begin{array}{l}\left(\mathrm{CH}_{3}\right) \\
\left(\mathrm{CH}_{2}\right)_{22}\left(\mathrm{CH}_{3}\right)\end{array}$ & $n$-Tetracosane & 52 \\
\hline
\end{tabular}

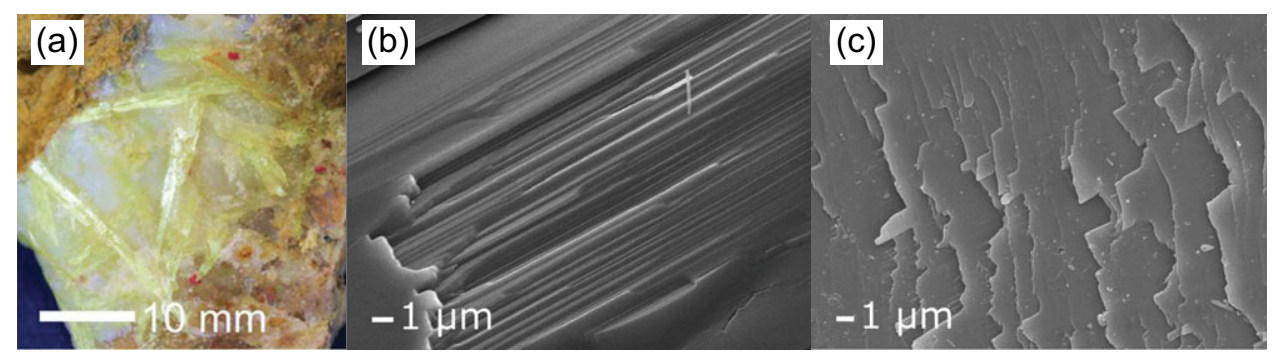

Figure 15.1 (a) A vein of karpatite (yellow crystals) surrounded by quartz (white crystals) and cinnabar (red spots). Scanning electron micrographs of (b) the broken surface of native karpatite and (c) its layering at the end of the layered structure.

Reproduced with permission of Springer Nature, from Potticary et al. (2017), Sci Rep, 7, 9867, figures 1b, 2a,b. ${ }^{46}$

relationship was established between these resinous bitumen and hydrothermal crystalline hydrocarbons identified as karpatite $\left(\mathrm{C}_{24} \mathrm{H}_{12}\right)$ and idrialite $\left(\mathrm{C}_{22} \mathrm{H}_{14}\right)$ found in the same rock samples and thought to derive from serpentinization reactions. ${ }^{38}$

Karpatite (Figure 15.1) and idrialite correspond to polycyclic aromatic hydrocarbon (PAH) minerals. PAH minerals are the most typical molecular organic minerals with welldefined chemical compositions and crystallographic properties. ${ }^{39}$ These molecular crystals can form thanks to the high stability of PAHs in hydrothermal fluids, ${ }^{40}$ allowing transport without thermal degradation and subsequent concentration and crystallization at the hydrothermal discharge zone. ${ }^{41,42}$ Coronene and phenanthrene, the precursors of karpatite and of a number of natural molecular organic minerals (Table 15.1), were shown to derive from the hydrothermal alteration of organic matter present in sediments, ${ }^{43}$ but can also be produced during basalt cooling (Section 15.3.4). ${ }^{44,45}$ Although the mechanisms of PAH concentration prior to crystallization is still unknown, occurrences of molecular organic 
minerals may attest to localized high concentrations in (poly)aromatic compounds in the oceanic lithosphere.

More recently, three studies characterized by bulk molecular approaches (1) serpentinized peridotites and gabbroic rocks recovered at the Atlantis Massif $\left(30^{\circ} \mathrm{N}\right.$ MAR) at both the Lost City hydrothermal field and Hole U1309D (Expeditions 304/305, Integrated Ocean Drilling Program (IODP)), ${ }^{26}$ (2) peridotites from the Ashadze $\left(12^{\circ} 58^{\prime} \mathrm{N}\right)$ and Logatchev hydrothermal sites along the MAR, ${ }^{53}$ and (3) the fossil ocean-continent transition recorded in the Swiss Alps. ${ }^{54}$ All of these studies used gas chromatography and/or gas chromatography-mass spectrometry. Based on the presence of biomarkers (e.g. pristane, phytane, squalane, hopanes, and steranes) or higher relative abundances of $n-\mathrm{C}_{16}$ to $n-\mathrm{C}_{20}$ alkanes, ${ }^{26,54}$ amino acids, and long-chain $n$-alkanes ${ }^{53}$ identified in the solvent-extracted fraction, they all concluded that the organic carbon was of biological origin, as supported by TOC isotopic analysis of the oceanic rocks. ${ }^{25,28}$ However, biological contamination may have overprinted any possible abiotic geochemical signatures ${ }^{26}$ since these oceanic basement rocks have been affected by long-lived hydrothermal alteration and present-day microbial ecosystems. ${ }^{29-31}$

\subsubsection{In Situ Investigations at the Microscale}

Development of in situ techniques currently allows imaging of rock-hosted CM along with their relationship with mineral parageneses. The scarce data for oceanic rocks report that the carbon phases exhibit a structural organization varying from amorphous to wellorganized graphite-like material (Figure 15.2a and b). Organic compounds have also been detected as thin films or gel-like materials embedding minerals and filling microfractures (Figure 15.2c). As is detailed below, some have an origin that is still debated, depending on the geological setting and textural criteria.

The Hyblean basaltic diatreme (Sicily, southern Italy), recognized as a paleo-oceanic serpentinite-hosted hydrothermal system comparable to those found along slow-spreading ridge segments, ${ }^{57}$ is one of the most studied places where the presence of large amounts of putatively abiotic carbonaceous compounds has been related to hydrothermal activity. A series of papers reported the occurrence of heavy hydrocarbons in deep-seated xenoliths including metasomatic gabbroic xenoliths ${ }^{47}$ and highly serpentinized peridotite xenoliths. ${ }^{58}$ In the gabbroic xenoliths, the presence of saturated aliphatic and aliphatic-aromatic hydrocarbons was highlighted by bulk rock analysis using electron impact-direct pyrolysis mass spectra. These observations were supported by Fourier-transform infrared (FTIR) spectroscopy showing carbon-cored clayey vesicles and dull-black, tiny pellets associated with the clayey mat pervasively intruding into fractures of the host rocks. ${ }^{47}$ Organic crystalline phases were also detected using X-ray diffraction (Table 15.1), and thermal decrepitation allowed the analysis of hydrocarbons trapped in fluid inclusions. Similarly, in the extensively serpentinized and carbonated ultramafic xenoliths, microscopic accumulations of sulfur-bearing organic matter commonly occur between hydrothermal minerals 

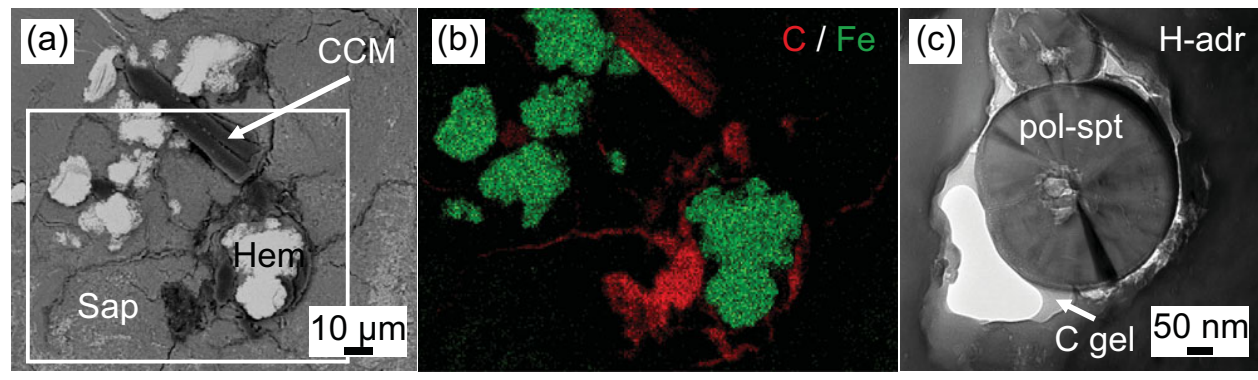

Figure 15.2 Examples of occurrences of organic carbon in serpentinized oceanic rocks. (a) Scanning electron micrograph of O-bearing condensed carbonaceous matter (CCM) abiotically formed jointly with hematite (Hem) and saponite (Sap) during the low-T alteration $\left(\mathrm{T}<150^{\circ} \mathrm{C}\right)$ of oceanic serpentinites of the Ligurian Tethyan ophiolites. (b) Associated elemental distributions of carbon (red) and iron (green) within the square area in (a). Reproduced with permission of Springer Nature, from Sforna et al. (2018), Nat Commun, 9, 5049, figure 2c and d. ${ }^{55}$ (c) Transmission electron micrograph showing polyhedral serpentine (pol-spt) sections wet by a jelly film of organic carbon interfacing between the pol-spt and an andraditic hydrogarnet (H-adr) in serpentinites from the MAR $\left(4-6^{\circ} \mathrm{N}\right)$. In these rocks, organic carbon was shown to mediate the nucleation and growth of polyhedral and polygonal serpentine from the hydrogarnet.

Reproduced with permission of Elsevier, from Ménez et al. (2018), Lithos, 323, 262-276. ${ }^{56}$

(i.e. secondary calcites and fibrous phyllosilicates), forming occasionally coarse bituminous patches. ${ }^{58}$ The organic matter was estimated to represent $3-6 \%$ of the whole rock. Micro-FTIR spectroscopy highlighted the presence of condensed aromatic rings with aliphatic tails consisting of a few $\mathrm{C}$ atoms, which is suggestive of asphaltene-like structures. Such structures were confirmed by solubility tests in toluene and $n$-hexane, thermogravimetric analyses and differential thermal analysis. X-ray photoelectron spectroscopy (XPS) also indicated minor $\mathrm{S}$ and $\mathrm{O}$ functional groups.

In these studies, it has been proposed that asphaltenes and high-molecular-weight hydrocarbons, respectively, derived from in situ aromatization or progressive polymerization and polycondensation reactions of light aliphatic hydrocarbons formed by FTT reactions. ${ }^{47,58}$ The hydrocarbon-bearing xenoliths possibly represent any level of the hydrothermal system, including its deepest and hottest parts at $\sim 400^{\circ} \mathrm{C} .^{47}$ Nevertheless, both biotic and abiotic origins could have been possible. It is challenging to infer the possible processes and formation conditions giving rise to heavy hydrocarbon accumulations in such a complex geologic setting. Mantle xenoliths experienced transport and decompression during the formation of the diatreme, with possible consequences for $\mathrm{CM}$ that are unrelated to hydrothermal circulation.

Indeed, CM commonly occurs in basalts and mantle xenoliths, which were thoroughly investigated during the $1980 \mathrm{~s}$ and $1990 \mathrm{~s} .{ }^{59-62}$ At that time, the aim was to assess the mantle carbon content by using a suite of techniques including electron microscopy, chemical imaging, XPS, and carbon isotopes, ${ }^{59,61-63}$ as well as thermal desorption surface analysis by laser ionization and low-energy electron diffraction. ${ }^{62}$ In these rocks, CM was 
observed as discrete platy lumps of up to $20-200 \mu \mathrm{m}$ in size or as thin, amorphous films of a few nanometers located on quench-produced crack surfaces, grain boundaries, and the walls of fluid inclusions. They consisted dominantly of graphite-intercalated compounds along with ill-defined complex mixtures of graphite-like compounds and organic material composed of $\mathrm{C}, \mathrm{H}$, and possibly $\mathrm{N}$. All of these studies concluded that $\mathrm{CM}$ had an abiotic origin based on: (1) its preferential concentration on sulfide spherules attached to vesicle walls, ${ }^{60}$ where the sulfides may have played a catalytic role in organic compound formation and concentration as also observed for hydrothermal sulfides; ${ }^{38}$ or (2) the close association of carbon with $\mathrm{Si}, \mathrm{Al}$, alkalis, halogens, and/or transition metals, which are elements that were likely present in the volcanic gas at the origin of these carbon accumulations. ${ }^{62}$ Again, to account for the production of $\mathrm{CM}$ in basalts and mantle xenoliths, these studies invoked: (1) FTT reactions involving volcanic gases degassed of host lava and reacting with fresh and chemically active crack surfaces formed by thermal stresses during eruption, decompression, and cooling; and (2) subsequent evolution of the condensate during cooling. Although heterogeneous catalysis at the mineral surface was the favored hypothesis, organics may have been alternatively assimilated into the volcanic gases prior to eruption and deposited on cracks formed during eruption and cooling. ${ }^{62}$

The possible role of mineral surfaces in the abiotic formation of $\mathrm{CM}$ in the oceanic lithosphere was pointed out in a series of recent studies. Various associations between minerals and condensed CM were documented using scanning electron microscopy (SEM) and Raman spectroscopy within magma-impregnated, mantle-derived serpentinites of the Ligurian Tethyan ophiolites, in a context of common occurrences in the lower oceanic crust (Figure 15.2a and b). ${ }^{55}$ Three distinct types of CM in paragenetic equilibrium with low-T mineralogical assemblages have been sequentially formed at decreasing $\mathrm{T}$ during the hydrothermal alteration of the rock assemblage. The first type corresponds to thin films of aliphatic chains, coating hydroandraditic garnets in bastitized pyroxenes. The second type forms micrometric aggregates associated with the alteration rims of spinel and plagioclase. The third and most massive type appears as large aggregates (up to $200 \mu \mathrm{m}$ in size) bearing highly aromatic carbon and short aliphatic chains associated with hematite and Fe-saponite assemblages replacing the pseudomorphoses after plagioclase (Figure 15.2a and $\mathrm{b}$ ). The systematic association of a given type of CM with a specific mineral paragenesis indicates that condensed CM precipitated simultaneously to the growth of the host mineralogical assemblage, overall in favor of an abiotic endogenesis. The mineral formation would have been accompanied by the production of $\mathrm{H}_{2}$ able to reduce carbon species, as is the case when ferric hydrogarnets and ferric serpentines form $^{64-66}$ or when spinel oxidizes to Cr-magnetite forming ferritchromite rims. ${ }^{67}$ This possible abiotic pathway was not considered in former studies performed on hydrogarnethosted carbonaceous compounds that suggested, based on their biological Raman and FTIR spectroscopy signatures, that this disordered CM may have resulted from the hydrothermal alteration of cryptoendolithic microbial ecosystems. ${ }^{30,31}$ Overall, while the involved mechanisms and reactants are still unknown, this recent study emphasizes a key role of local parageneses forming unique microenvironments prone to the synthesis of 

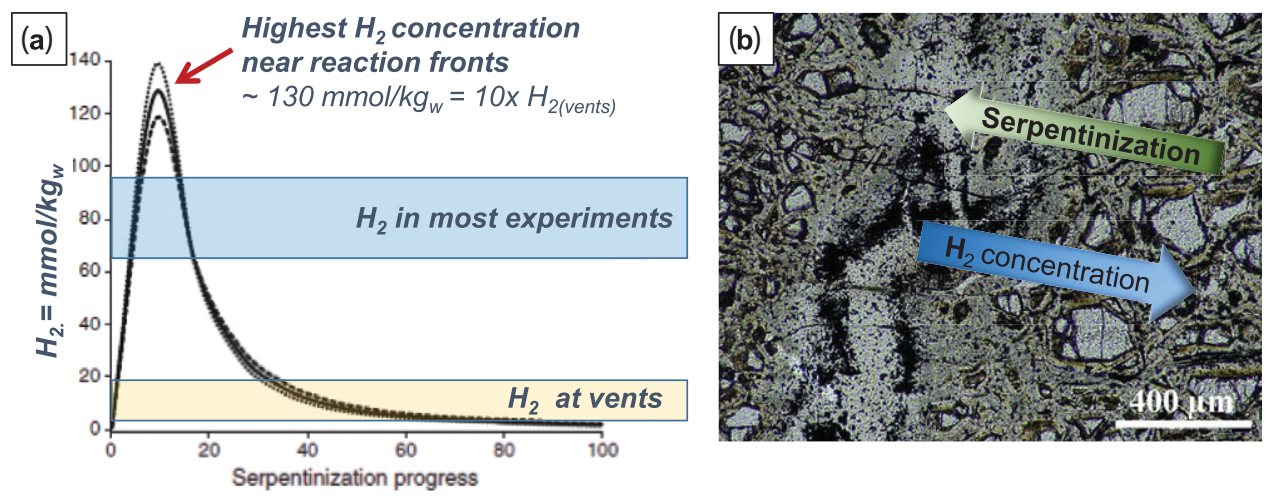

Figure 15.3 (a) Evolution of $\mathrm{H}_{2}$ concentration in hydrothermal fluid as a function of serpentinization degree estimated from mass balance calculation on $\mathrm{Fe}^{2+}$ and $\mathrm{Fe}^{3+}$ in abyssal peridotite. (b) Differences in $\mathrm{H}_{2}$ concentrations, generated by the spatial heterogeneity of reaction, create a redox gradient between partly and fully serpentinized areas down to the micrometric scale.

Modified with permission of Elsevier, from Andreani et al. (2013), Lithos, 178, 70-83, figure 9b. ${ }^{64}$

abiotic hydrocarbon. ${ }^{55}$ The productivity could have been also controlled by the local presence of catalysts such as $\mathrm{Cr}^{3+}$ in hydrogarnets or Fe-saponite in addition to specific redox conditions among the large redox potential gradients existing in serpentinizing systems down to the microscale (Figure 15.3). ${ }^{64}$

The catalytic role of phyllosilicates in abiotic organic synthesis has been suggested by the syngenetic link between phyllosilicates and organic compounds in several hydrothermal systems. The abundance of long-chain aliphatic and aromatic hydrocarbons (identified using FTIR spectroscopy) has been reported in a diapir of saponite-dominated clays intruded in a diatremic tuff-breccia deposit. ${ }^{68}$ The clays formed during the high-T $\left(350-400^{\circ} \mathrm{C}\right.$ ) hydrothermal alteration of mafic and ultramafic lithologies in the Hyblean crustal basement. Based on the close association of hydrocarbons with hydrothermal clays, the lack of fossils, and the resemblance with the previously described xenolith-hosted organic compounds, ${ }^{47,58}$ a possible abiogenic origin was suggested for the hydrocarbons via FTT reactions mediated by the organoclay. A close association of organic compounds with clays minerals such as saponite has been previously described in interplanetary dust ${ }^{69}$ and in carbonaceous meteorites that have undergone significant aqueous alteration processes. ${ }^{70-72}$ A similar association was recently highlighted at a micrometric scale using FTIR spectroscopy in oceanic serpentinites collected at $\sim 170 \mathrm{~m}$ depth below seafloor during the IODP Expeditions 304/305 targeting the Atlantic Massif. ${ }^{73}$

Overall, all of these studies highlight that hydrothermally derived organic carbon trapped within the upper lithosphere as heavy and aromatic compounds can be chemically and structurally diverse, although formation mechanisms are not yet well-known. Whether aromatization occurs in situ from $\mathrm{CO}_{2} / \mathrm{CO}$ and $\mathrm{H}_{2}$ during serpentinization or derives from progressive polymerization and polycondensation reactions of light aliphatic \pm aromatic hydrocarbons inherited from higher-T FTT reactions still needs to be addressed. This latter 
scenario implies that reactants for the low- $\mathrm{T}\left(<400^{\circ} \mathrm{C}\right)$ hydrothermal synthesis of abiotic organic compounds that may occur during serpentinization might be more diverse than $\mathrm{H}_{2}$ and $\mathrm{CO}_{2} / \mathrm{CO}$ and account for aliphatic and aromatic compounds, as supported by the presence of molecular organic minerals in serpentinized rocks (Sections 15.2.1 and 15.2.2). ${ }^{38,47}$

\subsubsection{Carbon in Fluid Inclusions Trapped in the Oceanic Lithosphere}

Fluid inclusions are used to document the composition of high-T fluids (either of magmatic or seawater origin) circulating in the lower crustal component of hydrothermal systems. Hence, they can inform on the intermediate abiotic processes that may happen at higher $\mathrm{T}$ and then feed with diverse reactants the low-T hydrothermal reactions, including organic synthesis. Fluid inclusions are made of liquid and/or gas with or without tiny daughter minerals that are trapped within a crystal structure during either primary crystallization or secondary healing of fluid-filled cracks. They occur throughout the gabbroic and peridotitic plutonic crust $^{74}$ and have been vastly studied by Raman spectroscopy and microthermometry. In ophiolites, fluid inclusions formed in sub-seafloor rocks may be preserved during tectonic uplift and maintain their original chemical signatures. This has been shown for pure methane fluid inclusions occurring in olivine from partially serpentinized harzburgites and dunites from the Nidar ophiolite complex (eastern Ladakh, India) ${ }^{75}$. In oceanic rocks, all studies have pointed to the presence of $\mathrm{CH}_{4} \pm \mathrm{H}_{2} \pm \mathrm{CO}_{2}$ within fluid inclusions, ${ }^{9,10,74,76,77}$ although propane and ethane were also sometimes reported in the gaseous phases. ${ }^{78}$ Analyses of fluid inclusions in primitive olivine gabbros, oxide gabbros, and evolved granitic rocks recovered from the slow-spreading Southwest Indian Ridge at Ocean Drilling Program Hole 735B (Atlantis II fracture zone) recorded $\mathrm{CH}_{4}$ concentrations 15-40 times those of hydrothermal vent fluids from sediment-poor environments and of basalt-derived volcanic gases. ${ }^{10,74}$ These studies also frequently reported the presence of disordered graphite, carbonaceous compounds, and putative graphite coating inclusion walls. $9,74,76$

While several processes were proposed to explain the presence of organic compounds in high-T hydrothermal fluids, ${ }^{79,80}$ fluid inclusions are generally believed to represent evolved magmatic fluids dominated by $\mathrm{CO}_{2}$ or CO. ${ }^{9,10,74}$ Indeed, subsequent to devolatilization and re-equilibration, graphite precipitation is promoted by re-speciation of magmatic $\mathrm{CO}_{2}$, and the formation of $\mathrm{CH}_{4}$-enriched fluids is promoted by cooling from $800^{\circ} \mathrm{C}$ to $500^{\circ} \mathrm{C}$ of these $\mathrm{H}_{2}$-rich fluids. Alternatively, re-speciation and reduction of entrapped $\mathrm{CO}_{2}$-bearing magmatic fluids by diffusion of external $\mathrm{H}_{2}$ into the inclusions during cooling was also considered. ${ }^{9,74}$ Once trapped within crystals as fluid inclusions, the fluids can still evolve following reactions between the fluid and the host mineral. Direct evidence for in situ $\mathrm{H}_{2}$ production and strongly reducing conditions within serpentinizing olivine fluid inclusions was provided for the Mineoka ophiolite complex considered as an analog to serpentinite-hosted hydrothermal vent systems. $^{81}$ In the latter study, mineral-phase 
equilibria indicated that $\mathrm{CH}_{4}-\mathrm{H}_{2}$-bearing fluids were trapped under equilibrium conditions at $\mathrm{T}$ below $300^{\circ} \mathrm{C}$, and the absence of $\mathrm{CO}_{2}$ was suggestive of extensive reduction of $\mathrm{CO}_{2}$ to $\mathrm{CH}_{4}$ within the inclusions. ${ }^{81}$ Whether $\mathrm{CH}_{4}$ was also produced at higher $\mathrm{T}$ remains an open question. The presence of $\mathrm{H}_{2}$ and $\mathrm{CH}_{4}$ together with secondary mineral microinclusions was similarly reported in olivine and orthopyroxene crystals from a harzburgite from the northern Oman ophiolite considered to be similar to abyssal peridotite. ${ }^{82}$ In olivine, the mineral inclusions mainly consisted of lizardite and brucite with small amounts of magnetite, while in orthopyroxene they were made of talc and chromian spinel. The differential in situ production of reduced gas and secondary phases was related to the presence of either magnetite or a magnetite component in chromium spinels. ${ }^{82}$ Alternatively, both $\mathrm{H}_{2}$ and $\mathrm{CH}_{4}$ inherited from high-T magmatic processes could have hydrothermally evolved differentially depending on the reactivity of their mineral host (e.g. its capacity to produce in situ $\mathrm{H}_{2}$ or to form mineral byproducts able to catalyze organic synthesis, as discussed in Section 15.2.2).

The presence of reduced carbon species in fluid inclusions within oceanic gabbros and mantle peridotites could represent a potentially important source of organic compounds in hydrothermal fluids. ${ }^{7,8,10}$ In particular, $\mathrm{CH}_{4}$-rich aqueous fluids trapped in the oceanic lithosphere within fluid inclusions recently redrew attention as they could constitute the main source of methane venting at unsedimented mid-ocean ridge hydrothermal fields. ${ }^{9,10,74,77,83}$ Similar processes were invoked to explain elevated concentrations of both $\mathrm{CH}_{4}$ and $\mathrm{H}_{2}$ in fluids from the Menez Gwen ( $37^{\circ} 50^{\prime} \mathrm{N}$, MAR), Lucky Strike ( $37^{\circ} 17^{\prime} \mathrm{N}$, MAR), and Piccard (Mid-Cayman Ridge) vent fields usually referred to as basalt-hosted vents supposedly less rich in reduced gases compared to ultramafic rock-hosted vents, ${ }^{20}$ despite the possible production of non-negligible amounts of $\mathrm{H}_{2}$ by diking-eruptive events. $^{84}$

Overall, in agreement with Section 15.2.2, studies on fluid inclusions emphasize the need to consider a larger range of reactants in addition to $\mathrm{CO}_{2} / \mathrm{CO}$ and $\mathrm{H}_{2}$ for low-T hydrothermal synthesis of abiotic organic compounds. This includes methane and light hydrocarbons, but also potentially reactive graphitic phases. Due to their tiny size and their entrapment in minerals, the latter are extremely challenging to analyze, and most of the previous studies seldom went further in characterizing the chemical diversity and degree of structural order of this $\mathrm{CM}$. The precipitation of highly crystalline hydrothermal graphite from aqueous fluids containing $\mathrm{CO}_{2}$ and $\mathrm{CH}_{4}$ was reported at $\mathrm{T}$ as low as $500^{\circ} \mathrm{C}$ during the propylitic hydrothermal alteration of volcanic host rocks. ${ }^{85}$ Other studies, targeting different geodynamical contexts, have shown that precipitation of $\mathrm{CM}$ in fluid inclusions, notably on their walls, can lead to graphitic material with varying degrees of crystallinity and disorder. ${ }^{86-89}$ Disordering in graphite is principally caused by in-plane defects and/or heteroatoms (e.g. O, N, S) ${ }^{90}$ While crystalline graphite was shown to be highly refractory and chemically inert, the chemical reactivity of graphitic carbon increases with structural disorder and the abundance of heteroatoms and unsaturations. ${ }^{91}$ Hence, this possibly impacts the diversification of abiotic organic compounds observed in the altering oceanic lithosphere. 


\subsection{Comparison with Experiments and Thermodynamic Predictions}

The heterogeneity of natural systems and the multistage character of hydrothermal alteration seem crucial for organic synthesis. This considerably complicates the identification of organic products, their origin, and the abiotic reaction sequences. A complementary experimental and theoretical approach is therefore mandatory to unraveling reaction paths and rates and determining the most favorable conditions that may lead to the abiotic formation of CM. The literature reviewed in the next sections highlights the gap between natural observations and experiments (Sections 15.3.1-15.3.3) and opens a wide field for future investigation, supported by thermodynamic predictions (Section 15.3.4).

\subsubsection{Experimental Approach}

Most of the experimental work dedicated to hydrothermal organic synthesis has focused on fluids, especially on the production of volatile organic compounds, using either monophasic (pure liquid) or biphasic (liquid + gas) systems. Solid mineral phases have not been systematically introduced in the experimental devices, and potential carbonaceous phases were rarely characterized after experiments. When present, minerals were either used as reactants, such as olivine to produce $\mathrm{H}_{2}$, or as redox buffers such as the hematite-magnetite (HM), hematite-magnetite-pyrite (HMP), pyrite-pyrrhotite-magnetite (PPM), or quartzfayalite-magnetite (QFM) assemblages. Minerals have also been introduced as potential catalysts of organic reactions. ${ }^{92-94}$ Unfortunately, they were never characterized after experiments, precluding the finding of $\mathrm{CM}$ occurrences.

Hence, the role of minerals on the formation of carbonaceous compounds under hydrothermal conditions, as emphasized from natural observations, has remained largely unexplored. This is partly explained by the analytical difficulty of detecting such a small organic fraction within the solid products (concentration close to or below detection limits) and of locating and characterizing it with high-resolution methods. In addition, contamination issues (from the experimental setup or deriving from organic compounds preexisting in the minerals used; e.g. trapped in fluid inclusions) remain central when looking for low levels of organic products whose nature is unknown and difficult to address.

The role of the experimental container (vessel or capsules) on $\mathrm{CO}_{2}$ reduction or $\mathrm{H}_{2}$ production reactions under hydrothermal conditions is potentially non-negligible while not clearly established. Stainless steel reactors have been shown to accelerate FTT reactions ${ }^{95,96}$ compared to quartz, glass, or $\mathrm{Au}$ and $\mathrm{TiO}_{2}$ reactors. However, stainless steel reactor walls may be passivated after several hours of experimental runs. ${ }^{95}$ That is also the case for titanium, whose oxidation can be a source of $\mathrm{H}_{2}$ if a preoxidation is not done prior to experiments. Gold, in the form of nanorods or particles, is well known to catalyze aqueous $\mathrm{CO}_{2}$ reduction to $\mathrm{CO}$ during electrochemical experiments, ${ }^{97,98}$ but it is not usually considered for hydrothermal experiments, probably because $\mathrm{CO}$ was either not measured or not abundant in products, and also because the gold liner is seen as a smooth surface. Hence, vessels or capsules made of gold or oxidized titanium are usually thought to be the 
most inert materials and are often preferred at high pressure $(\mathrm{P})$ and $\mathrm{T}$ to stainless steel, platinum, alumina, or hastelloy (Ni-Fe-rich alloy). The effect of hastelloy may depend on the reaction of interest. It was infrequently used for FTT reactions, probably because of the potential catalytic properties of the Ni-rich metal alloy, but it was used for $\mathrm{H}_{2}$ production. ${ }^{99}$ Its catalytic effect has not yet been demonstrated for such reactions. The use of Teflon ${ }^{\mathrm{TM}}$ especially may be a direct source of carbon contamination with increasing T. Concerning reactor permeability to gas, $\mathrm{H}_{2}$ has a high diffusivity in most metals, but $\mathrm{H}_{2}$ loss is expected to be relatively low at $\mathrm{T}<400^{\circ} \mathrm{C}^{100}$

Hence, there is no homogeneity in the type of reactor used in the literature, which often precludes comparison between results, especially when the mineral effect has to be unraveled. In addition, the possible precipitation of a carbonaceous phase on the reactor wall has never been investigated.

\subsubsection{Carbon-Bearing Reactants in Experiments}

Oceanic hydrothermal systems developing near ridge axes have two main sources of inorganic carbon: (1) mantle-derived carbon delivered by magmatic activity in which $\mathrm{CO}_{2}$ dominates in the $\mathrm{C}-\mathrm{O}-\mathrm{H}$ system, with very minor $\mathrm{CO}$ and $\mathrm{CH}_{4} ;{ }^{1}$ and (2) dissolved inorganic species that result from the equilibration of atmospheric $\mathrm{CO}_{2}$ and seawater. Hence, aqueous $\mathrm{CO}_{2}\left(\mathrm{CO}_{2(\mathrm{aq})}\right)$ and bicarbonate and carbonate ions $\left(\Sigma \mathrm{CO}_{2}\right)$ are usually the most abundant species in solutions and are the preferential sources of carbon used in experiments and models designed to test abiotic organic synthesis under hydrothermal conditions mimicking natural systems.

Nevertheless, $\Sigma \mathrm{CO}_{2}$ are not the only single-carbon compounds possibly available at equilibrium in hydrothermal fluids, especially if $\mathrm{H}_{2}$ is available. Experiments have shown that the speciation of aqueous single-carbon compounds in the $\mathrm{C}-\mathrm{O}-\mathrm{H}$ system for $\mathrm{T}=150-300^{\circ} \mathrm{C}$ and $\mathrm{P}=35 \mathrm{MPa}$ is controlled by reactions between $\Sigma \mathrm{CO}_{2}, \mathrm{CO}, \Sigma \mathrm{HCOOH}$ ( $\mathrm{HCOOH}$, formic acid $+\mathrm{HCOO}^{-}$, formate), $\mathrm{CH}_{2} \mathrm{O}$ (formaldehyde), $\mathrm{CH}_{3} \mathrm{OH}$ (methanol), and $\mathrm{CH}_{4}$ (Figure 15.4). ${ }^{101}$ Indeed, the water-gas shift reaction (15.1) under aqueous hydrothermal conditions leads to the formation of $\Sigma \mathrm{HCOOH}$ as an intermediate product (Figure 15.4):

$$
\mathrm{CO}+\mathrm{H}_{2} \mathrm{O}=\mathrm{CO}_{2}+\mathrm{H}_{2}
$$

$\Sigma \mathrm{HCOOH}$ reaches a redox-dependent equilibrium with methanol, formaldehyde, and $\mathrm{CH}_{4}$ within few days at $\mathrm{T}>150^{\circ} \mathrm{C}$, but may need years at $\mathrm{T}<100^{\circ} \mathrm{C} .{ }^{101}$ Formaldehyde and $\mathrm{CH}_{4}$ were close to below detection limits in the experiments, suggesting kinetic inhibition at least for the P-T range tested. ${ }^{101}$ In the absence of $\mathrm{CH}_{4}$, the relative concentrations of single-carbon compounds in fluids strongly depended on $\mathrm{T}, \mathrm{H}_{2}$ fugacity $\left(f \mathrm{H}_{2}\right)$, and $\mathrm{pH}$. Under neutral and acidic conditions, $\mathrm{CO}_{2}$ largely dominated, with minor amounts of $\mathrm{CO}$ and $\Sigma \mathrm{HCOOH}$ (several orders of magnitude $<\mathrm{CO}_{2}$ ) at $350^{\circ} \mathrm{C}$. At $150^{\circ} \mathrm{C}$ and similar 


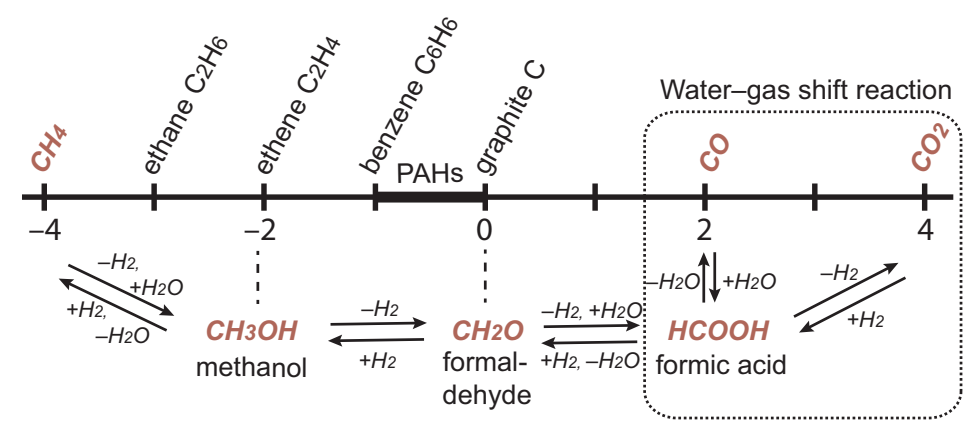

Figure 15.4 Oxidation states of carbon in some single-carbon organic compounds. The water-gas shift reaction (15.1) is represented along with the successive reversible redox reactions that control the speciation of single-carbon compounds under hydrothermal conditions. ${ }^{44,101}$

$\mathrm{pH}$, methanol is predicted to be only one order of magnitude below $\mathrm{CO}_{2}$ with minor $\mathrm{CO}$ and $\Sigma \mathrm{HCOOH}$, but it could exceed $\mathrm{CO}_{2}$ if the $\mathrm{H}_{2}$ concentration increased to values similar to those measured at ultramafic rock-hosted hydrothermal vents (i.e. $\sim 10 \mathrm{mM}^{102}$ ). Under alkaline conditions, the formate concentration can be equivalent to bicarbonate with decreasing $\mathrm{T}$ or increasing $\mathrm{H}_{2}$ concentrations.

Direct formation of methanol ( $1 \mathrm{mM}$ max) from a $\mathrm{H}_{2}-\mathrm{CO}_{2}$-rich vapor phase can also occur, with a limited conversion rate $\left(10^{-4} \%\right)$ at $300-350^{\circ} \mathrm{C}(18 \mathrm{MPa})$, provided magnetite surfaces are available. ${ }^{95}$ This could be realistic at mid-ocean ridges (e.g. following dike emplacement with volatile exsolution and migration in adjacent oxide gabbro or in serpentinized peridotites where magnetite is abundant). Magnetite shows decreasing surface reactivity with time and can be regenerated with increasing $\mathrm{T}$, suggesting that it may serve as a catalyst during successive diking events, for instance. The authors do not preclude possible intermediates such as $\mathrm{CO}$ and $\Sigma \mathrm{HCOOH}$ in the redox reaction, but these compounds were not detected or measured, respectively, and no graphitic phase or alkanes were observed. ${ }^{95}$

These works show that a large variety of single-carbon species can be available in fluids in addition to $\Sigma \mathrm{CO}_{2}$ (mainly methanol and formate), especially in natural serpentinizing systems with highly variable $\mathrm{pH}$ and local $\mathrm{H}_{2}$ levels. ${ }^{64}$ This is particularly true in low-T serpentinizing environments that may be dominated by methanol or formate depending on $\mathrm{pH}$, provided equilibrium is reached. This diversity reinforces the conclusions of Section 15.2 about the need to consider a wider range of carbon-bearing reactants for organic synthesis in natural systems and consequently in experiments. Natural systems also pointed to the possible availability of PAHs, $\mathrm{CM}$, and deep magmatic $\mathrm{CH}_{4}$ for low-T hydrothermal reactions. Except for formic acid, whose decomposition in aqueous fluid (Figure 15.4) is frequently exploited to experimentally produce $\mathrm{H}_{2}$ and $\mathrm{CO}_{2}$, these compounds have rarely (e.g. methanol ${ }^{103}$ ) or never been used as reactants in geologically relevant experiments.

$\mathrm{CH}_{4}$, which is abundant in hydrothermal fluids or cold seepages associated with the serpentinization of mantle rocks, ${ }^{3,102}$ was usually considered as the reduction product of 
inorganic carbon sources rather than as a possible reactant. An important experimental effort was deployed to reproduce methane synthesis by FTT reactions under moderate to low-T conditions $\left(\leq 500^{\circ} \mathrm{C}\right)$, but systematically failed to produce abundant $\mathrm{CH}_{4}$. The natural $\mathrm{H}_{2} / \mathrm{CH}_{4}$ ratio measured in serpentinization-related oceanic hydrothermal environments $(<30)^{102}$ remains much lower than experimental ones $\left(>500\right.$; except values at $42^{104}$ and $17 ;^{105}$ e.g. see $\mathrm{McCllom}^{106}$ for a review). This difference was proposed as an indication of the abiotic versus biotic origin of $\mathrm{CH}_{4}$ in natural systems, where intense $\mathrm{H}_{2}$ consumption and associated $\mathrm{CH}_{4}$ production can be attributed to biological activity. ${ }^{107}$ This simplistic criterion was refuted because it cannot account for the complex processes occurring in the environment, ${ }^{108}$ and it also disregarded some other parameters. The $\mathrm{H}_{2} /$ $\mathrm{CH}_{4}$ ratio may vary with $\mathrm{T}$, decreasing as $\mathrm{T}$ increases from $200^{\circ} \mathrm{C}$ to $500^{\circ} \mathrm{C}$ at $300 \mathrm{MPa} .{ }^{109}$ The effect of pressure has been seldom investigated, but a few studies have shown that increased pressure can account for a significant increase in the $\mathrm{CH}_{4}$ yield between 100 and $350 \mathrm{MPa}{ }^{110} \mathrm{CH}_{4}$ formation can also compete with $\mathrm{CO}_{2}$ carbonation depending on $\mathrm{fH}_{2}$, $\mathrm{CO}_{2}$ partial pressure, and T. At $200^{\circ} \mathrm{C}, \mathrm{CH}_{4}$ formation by $\mathrm{CO}_{2}$ reduction is limited by $\mathrm{H}_{2}$ production during olivine alteration if the system is supersaturated with respect to carbonate because the kinetics of carbonate precipitation are faster. Finally, the micromolar levels of $\mathrm{CH}_{4}$ often found in experiments might not even be produced by in situ reactions, but instead may represent contamination. This is often difficult to assess since blank experiments are rarely provided and ${ }^{13} \mathrm{C}$-labeled experiments are scarce. Contamination issues are critical in very-low-T experiments $\left(<100^{\circ} \mathrm{C}\right)$ where product levels are much lower and display contrasting values of $\mathrm{H}_{2}$ and $\mathrm{CH}_{4}$ despite similar protocols. ${ }^{13,67,111-115}$ The most complete investigation conducted so far at $\mathrm{T} \leq 100^{\circ} \mathrm{C}$ led to the formation of lowmolecular-weight organic acids (mainly formate and acetate); no $\mathrm{CH}_{4}$ was observed during $\mathrm{H}_{2}$ production by serpentinization. ${ }^{13}$ This suggests that at such low-T and moderately alkaline conditions $(\mathrm{pH} \sim 8)$, the inorganic carbon $\left(\mathrm{CO}_{2}, \mathrm{CO}\right.$, or bicarbonate) tends to equilibrate with organic acids instead of $\mathrm{CH}_{4}$ in a metastable assemblage as previously described for higher $\mathrm{T}\left(150-350^{\circ} \mathrm{C}\right) .^{14,15,101}$

Hence, the high $\mathrm{H}_{2} / \mathrm{CH}_{4}$ ratio observed in most experiments (e.g. run at $\sim 300^{\circ} \mathrm{C}, 30-50$ $\mathrm{MPa}$ ) highlights the kinetic inhibition of $\mathrm{CH}_{4}$ formation from the reduction of dissolved $\mathrm{CO}_{2}$ species or formate under aqueous hydrothermal conditions. ${ }^{14,15}$ For this reason, the role of realistic catalysts (magnetite, hematite, chromite, Fe-Ni alloys, or sulfides) has been tested to circumvent this limitation. Most of them allowed very limited conversion of inorganic carbon to $\mathrm{CH}_{4}(<1 \% \max )$ and even less for longer-chain alkanes $(\ll 0.1 \% \max )$ under laboratory timescales (several months), with a final $\mathrm{CO}_{2} / \mathrm{CH}_{4}$ ratio ranging from $100^{116}$ to $1000{ }^{14,15,117-119}$ Lower values of $\mathrm{CO}_{2} / \mathrm{CH}_{4}$, as small as $\sim 0.1-1.0$ and 10 , were obtained in studies using $\mathrm{Fe}-\mathrm{Ni}$ alloys (porous awaruite) ${ }^{104}$ or Ni-sulfides ${ }^{119}$ and Cobearing magnetite, ${ }^{105}$ respectively, pointing to some very specific catalysts possibly available in serpentinized peridotites. Conversely to $\mathrm{CO}_{2}$, hematite, magnetite, and $\mathrm{Fe}-\mathrm{Ni}$ alloys did not affect the stability of formate and formic acid, at least for $\mathrm{T}$ of $170-260^{\circ} \mathrm{C} .{ }^{15}$

The presence of a gaseous phase in the system, which creates conditions closer to the industrial Fisher-Tropsch process, also seems to favor a higher yield of $\mathrm{CH}_{4}$ and the 
formation of more complex hydrocarbons, ${ }^{15,96,106}$ even in the absence of a catalyst ${ }^{110}$ (if olivine and gold reactor walls are excluded). At very-low-T conditions, ${ }^{120} \mathrm{Ru}$-bearing chromitite exhibits efficient catalytic properties for $\mathrm{CH}_{4}$ production under gaseous conditions. The slow kinetics of the first step $\left(\mathrm{CO}_{2}\right.$ to $\mathrm{CO}$ reduction) in a gas phase is already well known in the industry, and chemists have strived to improve catalyst efficiency, notably by increasing the local concentration of $\mathrm{CO}_{2}$ on the catalyst surface by altering the catalyst's nature, shape, and size. ${ }^{98,121}$

Overall, these experiments seldom report on the potential presence of heavier organic compounds or on the organic content of the liquid ${ }^{122}$ and solid phases, if any are present (see Section 15.3.1), leaving the possibility for other type of products and reaction mechanisms to account for low $\mathrm{CH}_{4}$ contents. Mineral reactants also need to be systematically introduced in future works for a more realistic approach that fits better with the conditions of natural systems (Section 15.2).

\subsubsection{Experimental Occurrences of Carbonaceous Material}

Very few experiments have investigated CM phases and their relationship with minerals using bulk or in situ methods such as SEM or transmission electron miscroscopy (TEM) with or without XPS, Raman, and FTIR spectroscopy. As for the characterization of natural occurrences, these methods are seldom used together, limiting comparisons, and the exact nature of $\mathrm{CM}$ is usually unidentified.

As described in Section 15.2.2, in the oceanic lithosphere, CM can be first deposited at high $\mathrm{T}\left(>400^{\circ} \mathrm{C}\right)$ on mineral surfaces and cracks during magmatic degassing at depth and subsequent migration and cooling of mantle-derived fluids. Experiments designed to reproduce this process simulated the sudden cooling of a $\mathrm{C}-\mathrm{O}-\mathrm{H}$ magmatic gas over freshly cracked olivines. ${ }^{123}$ Evidence for direct carbon precipitation on newly formed cracks has been reported despite thermodynamically unfavorable experimental conditions for graphite precipitation. ${ }^{123}$ In this study, it was proposed that freshly cracked surfaces of olivine, and possibly of other silicates, offer chemically active areas facilitating the heterogeneous nucleation of $\mathrm{CM}$ during interaction with $\mathrm{C}-\mathrm{O}-\mathrm{H}$ gases, at least for initial $\mathrm{T}$ between $400^{\circ} \mathrm{C}$ and $800^{\circ} \mathrm{C}$. The deposited carbonaceous film displayed a more complex structure than graphite. Bonding was dominated by $\mathrm{C}-\mathrm{C}$ and $\mathrm{C}-\mathrm{H}$ species under the more oxidizing conditions tested, whereas the more reducing ones showed similar amounts of $\mathrm{C}-\mathrm{C}, \mathrm{C}-\mathrm{H}$, $\mathrm{C}-\mathrm{O}$, and metal- $\mathrm{C}$ species such as carbides $(\mathrm{SiC}$ or $\mathrm{MgC}) .{ }^{123}$ Carbides, mainly observed at $400^{\circ} \mathrm{C}$, could have acted as reaction intermediates for FTT reactions, but this has not been proven since the analyses of companion gases could not be performed in this study.

The thermal decomposition of siderite under water vapor conditions $\left(300^{\circ} \mathrm{C}\right)$ and saturated vapor pressure $\left(\mathrm{P}_{\text {sat }}\right)$ also resulted in the formation of CM. ${ }^{124}$ Siderite alone provides both $\mathrm{H}_{2}$ from water reduction by $\mathrm{Fe}^{2+}$ oxidation and inorganic carbon transformed into a reduced carbon phase (15.2):

$$
6 \mathrm{FeCO}_{3} \rightarrow 2 \mathrm{Fe}_{3} \mathrm{O}_{4}+5 \mathrm{CO}_{2}+\mathrm{C} .
$$


Although siderite may not be abundant in the oceanic lithosphere, other carbonates are present and may locally decompose (e.g. during magmatic injections) and react if $\mathrm{H}_{2}$ is available. After solvent extraction, the organic products were identified as dominantly alkylated and hydroxylated aromatic compounds, ${ }^{124}$ which considerably differs from the FTT products (aliphatic chains) that would have been catalyzed by the abundantly formed magnetite. In addition, discrepancies between the relative H/C ratios of reactants and products suggested the presence of an unidentified product with a low $\mathrm{H} / \mathrm{C}$ ratio, which could be an insoluble C-rich phase remaining in the solid phase. $^{124}$

Under aqueous conditions more representative of low-T hydrothermal processes, two types of experiments report the formation of a poorly crystallized CM: (1) alteration of ferromagnesian silicates by a $\mathrm{CO}_{2}$-enriched fluid; and (2) carbonate dissolution experiments.

Experiments involving the carbonation of olivine $\left(400-500^{\circ} \mathrm{C}, 100 \mathrm{MPa}\right.$, static capsules $\left.{ }^{125}\right)$ and of a sandstone made of $\mathrm{Fe}^{2+}$-rich volcanic clasts $\left(100^{\circ} \mathrm{C}, 10 \mathrm{MPa}\right.$, flowthrough reactor ${ }^{126}$ ) reported the precipitation of a poorly crystallized graphitic phase (Figure 15.5a and b). In both experiments, the graphitic phase accounts for a nonnegligible part of the reaction products in addition to phyllosilicates and carbonates. As in natural systems (Section 15.2.2), it is embedded in phyllosilicates, corresponding to serpentine (Figure 15.5a) or Fe-rich chlorite (chamosite; Figure 15.5b) here, closely associated with magnetite when present. ${ }^{126} \mathrm{CM}$ formation was attributed to the reduction of $\mathrm{CO}_{2}$ (or $\mathrm{CO}$ at high $\mathrm{P}-\mathrm{T}^{125}$ ) by $\mathrm{H}_{2}$ initially present in solution (Eqs. (15.3) and (15.4)) ${ }^{125}$ or by $\mathrm{Fe}^{2+}$-bearing minerals. ${ }^{126}$

$$
\begin{gathered}
\mathrm{CO}_{2}+2 \mathrm{H}_{2}=\mathrm{C}+2 \mathrm{H}_{2} \mathrm{O} . \\
\mathrm{CO}+\mathrm{H}_{2}=\mathrm{C}+\mathrm{H}_{2} \mathrm{O} .
\end{gathered}
$$

The two protocols described above resulted in different oxygen fugacities $\left(f \mathrm{O}_{2}\right)$. It was estimated to be close to the $\mathrm{CCO}$ buffer $(\mathrm{C}$ as graphite- $\mathrm{CO})$ in the high-P-T runs, ${ }^{125}$ which prevented the formation of magnetite, in opposition to the low-P-T runs. ${ }^{126}$ This indicates that magnetite is not mandatory for the formation of graphitic material, whose nature remains poorly constrained, however. Organic volatiles have not been investigated in these studies.

Siderite dissolution experiments at $200^{\circ} \mathrm{C}$ and $300^{\circ} \mathrm{C}$ and $50 \mathrm{MPa}$ described two types of carbonaceous products (Figure $15.5 \mathrm{c}$ and $\mathrm{d}$ ) ${ }^{127}$. A poorly structured hydrated or hydrogenated $\mathrm{CM}$ occurred without spatial relationship with minerals in all runs (Figure 15.5c). At $200^{\circ} \mathrm{C}$, a more ordered graphitic carbon formed on the surface of the neo-formed magnetite grains or near iron oxides at the siderite surface (Figure $15.5 \mathrm{~d}$ ). $\mathrm{CO}_{2}$ was the only gas detected at $200^{\circ} \mathrm{C}$, while additional small amounts of $\mathrm{H}_{2}$ and $\mathrm{CH}_{4}$ were detected at $300^{\circ} \mathrm{C}$. A blank experiment showed that trace amounts $(<\mathrm{mM})$ of dissolved organic compounds were present as contaminants. ${ }^{127}$ Although they were much less 

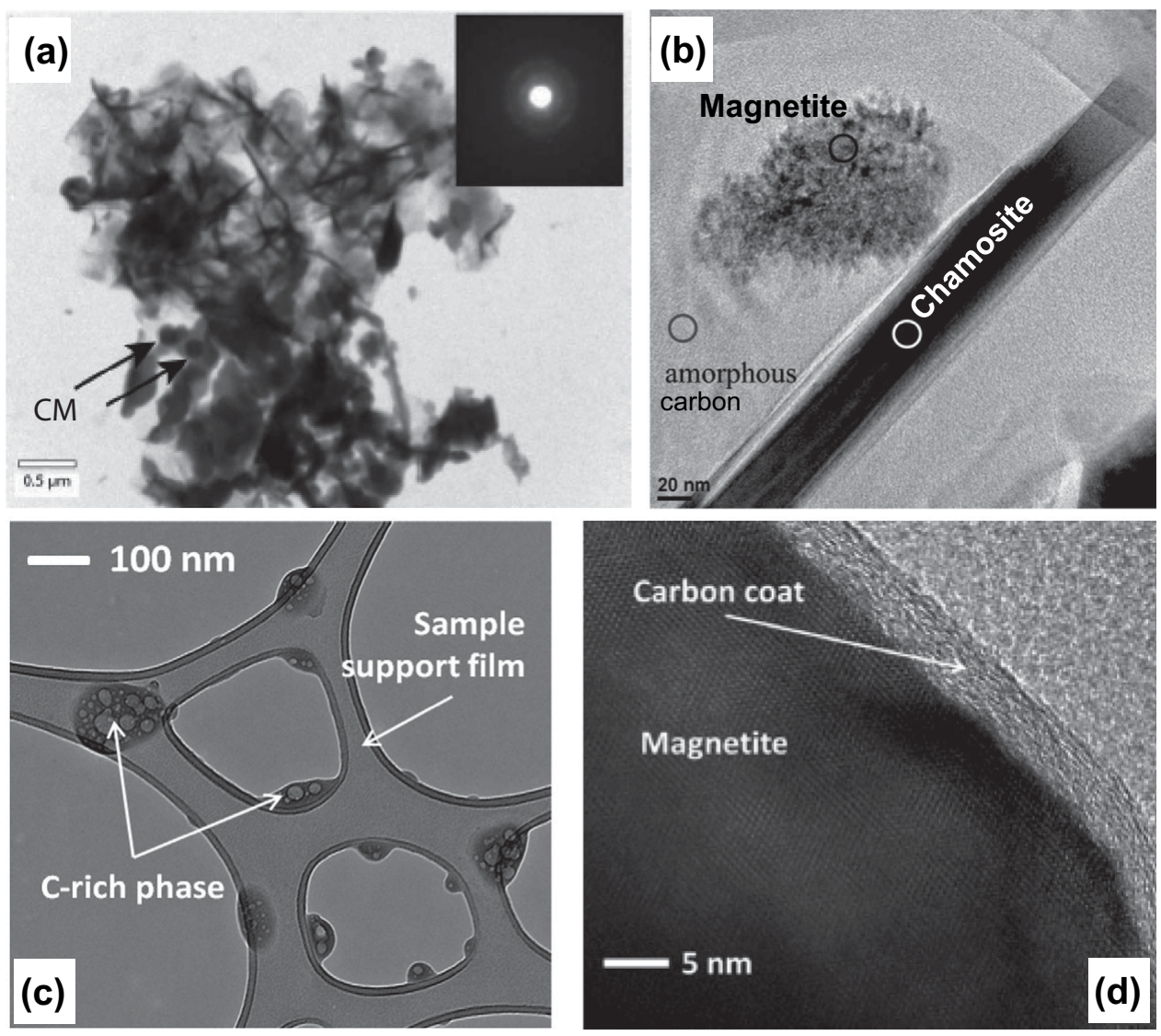

Figure 15.5 Examples of CM that precipitated in hydrothermal experiments. (a) Poorly crystallized graphitic phase (round particles) formed during high-T $\left(400-500^{\circ} \mathrm{C}\right)$ carbonation of olivine. (b) Amorphous carbon precipitation during low- $\mathrm{T}\left(100^{\circ} \mathrm{C}\right)$ carbonation of a sandstone made of $\mathrm{Fe}^{2+}$-rich volcanic clasts. (c, d) Two different types of CM precipitated during low-T (200-300 $\left.{ }^{\circ} \mathrm{C}\right)$ siderite dissolution: a poorly structured hydrated or hydrogenated carbonaceous phase (c) and a more ordered graphitic phase (d).

Reproduced with permission of Elsevier, from (a) Dufaud et al. (2009), Chem Geol, 265, 79-87, figure 6, ${ }^{125}$ (b) Luquot et al. (2012), Chem Geol, 294-295, 75-88, figure $10,{ }^{126}$ and (c, d) Milesi et al. (2015), Geochim Cosmochim Acta, 154, 201-211, figures 4 and 5a. ${ }^{127}$

abundant than $\mathrm{CO}_{2}$, there remain open questions regarding whether they contributed to the formation of low levels of $\mathrm{CH}_{4}$ and the presence of carbonaceous phases. Whatever the case may be, the results of this work fit well with kinetic inhibition of $\mathrm{CH}_{4}$ formation from $\mathrm{CO}_{2}$ and $\mathrm{H}_{2}$ at low $\mathrm{T}\left(<400^{\circ} \mathrm{C}\right.$; Section 15.3.2) and suggest a preferential precipitation of $\mathrm{CM}$ with decreasing $\mathrm{T}$ through reactions (15.3) and (15.5).

$$
3 \mathrm{FeCO}_{3}+\mathrm{H}_{2} \mathrm{O}_{(\mathrm{aq})}=\mathrm{Fe}_{3} \mathrm{O}_{4}+3 \mathrm{CO}_{2(\mathrm{aq})}+\mathrm{H}_{2(\mathrm{aq})} .
$$




$$
\mathrm{C}+2 \mathrm{H}_{2}=\mathrm{CH}_{4} \text {. }
$$

The inefficiency of magnetite as a FTT reaction catalyst is also pointed out here (see Section 15.3.2). Poisoning of the magnetite surface by carbon coatings (Figure 15.5d) at low $\mathrm{T}$ has been questioned; alternatively, the carbon coating may only form when $\mathrm{CH}_{4}$ cannot (i.e. at low T). A syngenetic relationship between $\mathrm{CM}$ and $\mathrm{CH}_{4}$ has also been proposed but not demonstrated. Equations (15.3) and (15.6) on the one hand and (15.7) and (15.8) on the other show two reversal genetic links. The second one (Eqs. (15.7) and (15.8)) appears less likely under the experimental conditions tested $\left(\leq 300^{\circ} \mathrm{C}\right)$ according, again, to the kinetic inhibition hampering $\mathrm{CH}_{4}$ formation (15.7).

$$
\begin{gathered}
\mathrm{CO}_{2}+4 \mathrm{H}_{2}=\mathrm{CH}_{4}+2 \mathrm{H}_{2} \mathrm{O} . \\
\mathrm{CO}_{2}+\mathrm{CH}_{4}=2 \mathrm{C}+2 \mathrm{H}_{2} \mathrm{O} .
\end{gathered}
$$

Equation (15.6), which suggests that carbon coating may serve as an intermediate step to $\mathrm{CH}_{4}$ formation at least at $300^{\circ} \mathrm{C}$ where its absence would result from its full consumption, may be a more relevant hypothesis, as already mentioned in Section 15.2.3. Similarly, it was previously suggested that background carbon, possibly more reduced than graphite on the magnetite surface, facilitates $\mathrm{CH}_{4}$ formation. ${ }^{118}$

At lower T compatible with life, experimental data are lacking on the formation of CM, while this is the condition under which it is the most difficult to discriminate the origin of $\mathrm{CM}$ in natural systems (Section 15.2). In serpentinization experiments run at $\leq 100^{\circ} \mathrm{C}$ (see Section 15.3.2), no $\mathrm{CH}_{4}$ was produced, and the strong decrease of $\mathrm{CO}_{2}$ and $\mathrm{H}_{2}$ after 3 months was not fully explained. ${ }^{13}$

The limited data available to describe the association of or interplay between organic volatiles and CM limit the conclusions so far on their genetic relationship.

If all occurrences of $\mathrm{CM}$ in experimental solid products are due to in situ abiotic reactions from an inorganic source (not contamination), they suggest that at least small amounts of $\mathrm{CM}$ easily form under a wide range of hydrothermal conditions during short runs of a few days to a few months $\left(100-500^{\circ} \mathrm{C}, 10-110 \mathrm{MPa}, f \mathrm{O}_{2}\right.$ between $\mathrm{CCO}$ and QFM buffers). The rare available images report different aspects (spherules, film-like surficial layers, or porous accumulations) similar to some of those observed in natural systems (Figure 15.2). They seem to condense from gas or precipitate from fluid preferentially on the mineral surfaces where they possibly evolve. Minerals used in experiments (mainly magnetite) were not as diverse as in nature (Section 15.2), and other mineral surfaces such as hematite, sulfides, hydrogarnets, phyllosilicates, epidote, and quartz, not yet introduced in experiments, may allow the formation of carbonaceous compounds, possibly when the reducing conditions are not optimal. ${ }^{38,55,60,85,123}$

In agreement with natural observations (Section 15.2.2), one experimental study has demonstrated that smectite clays, and particularly montmorillonites, can promote and preserve organic compounds formed under seafloor hydrothermal conditions $\left(300^{\circ} \mathrm{C}\right.$, $100 \mathrm{MPa}) .{ }^{103}$ While ${ }^{13} \mathrm{CH}_{4}$ was the dominant organic product in the gas-phase, aromatic 
compounds, including PAHs (up to $\mathrm{C}_{20}$ ), were extracted from the solid products that reacted for 6 weeks with labeled ${ }^{13} \mathrm{C}$-methanol $(10.4 \mathrm{M})$. The absence of organic material within the illite sample compared to the smectite one showed that the clay interlayer properties exert a control on organic synthesis, notably the negatively charged layer of smectite. The exact reaction path was not constrained; the role of alkanes as intermediate reactants or products and the presence of methanol as a major reactant are worth noting. This study also highlighted the possible protection of organic compounds by clays from thermal alteration at $300^{\circ} \mathrm{C}$, making them available for further reactions under lower- $\mathrm{T}$ conditions.

\subsubsection{Thermodynamic Predictions}

The nature of hydrothermal CM observed in natural and experimental works related to the alteration of mantle-derived rocks is not clarified yet. It ranges from graphite to very different forms in terms of structural order, nature and quantity of heteroatoms, unsaturations, and hence reactivity. There has been a considerable amount of work to quantify the thermodynamics of $\mathrm{C}-\mathrm{C}$ bond formation in graphite and other phases. ${ }^{32}$ We selected here the main results related to $\mathrm{CM}$ formation under hydrothermal conditions for comparison with previous sections.

The formation of graphite is predicted from $\mathrm{C}-\mathrm{O}-\mathrm{H}$ fluids under a wide range of hydrothermal conditions, provided there is no kinetic inhibition. Graphite can readily precipitate from the fluid; this is favored by a decrease in temperature or an increase in pressure along with a decrease in water content. ${ }^{36,45,128,129}$ Both $\mathrm{T}$ decrease (deep fluid ascent) and water decrease (e.g. during hydration reactions) correspond well to natural oceanic scenarios in the deeper part of the lithosphere. Graphite formation results from redox reactions unless the reactant carbon is at the same oxidation state (i.e. zero). This does not necessarily require very strong reducing conditions, and graphite can be produced through either oxidation or reduction reactions (Figure 15.4). ${ }^{44,130}$ In addition to graphite, $\mathrm{CO}_{2}$ or $\mathrm{CH}_{4}$ should be the dominant carbon species in hydrothermal fluids depending on temperature and oxygen fugacity. For a given oxygen fugacity, $\mathrm{CO}_{2}$ should predominate at high- $\mathrm{T}$ conditions, while $\mathrm{CH}_{4}$ is favored at the lower $\mathrm{T}^{35,131}$ according to the equilibrium described in (15.7).

When methane and graphite formation is inhibited (i.e. when the kinetic barriers hamper access to a stable equilibrium, ${ }^{35}$ as in most natural and experimental systems; Sections $15.2,15.3 .2$, and 15.3.3), there is considerable potential for the hydrothermal synthesis of a wide range of metastable organic molecules provided that $f \mathrm{H}_{2}$ is high enough. ${ }^{33,44,45}$ The reversible character of several organic reactions in hydrothermal fluids contributes to this variety (e.g. hydration/dehydration or oxidation/reduction reactions). ${ }^{132}$ Calculations have shown that organic synthesis of metastable phases is even possible in environments where the amount of $\mathrm{H}_{2}$ is usually below those observed during the alteration of mantledominated environments; ${ }^{44,45}$ as an example, the rapid cooling of volcanic gases 
containing $\mathrm{CO}, \mathrm{CO}_{2}, \mathrm{H}_{2} \mathrm{O}$, and $\mathrm{H}_{2}$ below $\sim 250^{\circ} \mathrm{C}$ provides a thermodynamic drive for the abiotic synthesis of metastable hydrocarbons such as condensed $n$-alkane and PAHs, depending on the $\mathrm{H} / \mathrm{C}$ ratio of the gas. Such products may relate to the complex $\mathrm{CM}$ and molecular organic minerals observed in natural samples and in $\mathrm{CH}_{4}$-poor experiments. In more reducing environments, the energetic drive of metastable compound formation is increased and reaction temperatures can be shifted to higher values. ${ }^{44,45}$ Decreasing temperature allows for metastable mixtures of different condensed phases, in agreement with the variety of compounds found in natural rock textures (Section 15.2.2).

The potential abiotic formation of $\mathrm{CM}$ during serpentinization that is central to this chapter has been investigated by comparing experimental fluid compositions with natural hydrothermal compositions across a wide range of $\mathrm{CO}_{2}$ concentrations. ${ }^{33}$ Predicted mineral assemblages consisted of serpentine and brucite with or without magnetite and carbonates depending on the relative activities of $\mathrm{H}_{2}$ and $\mathrm{CO}_{2} \cdot \mathrm{CO}_{2(\mathrm{aq})}$ was considered at equilibrium with graphitic compounds that share the thermodynamic properties of graphite and a hydrogenated aromatic carbon compound (i.e. anthracene, a PAH made of three benzene rings) in order to mimic the experimental products (Figure $15.5 \mathrm{c}$ and d). ${ }^{33,127}$ Results show that serpentinization fluids can equilibrate with both the graphitic and the hydrogenated carbon when the formation of alkanes is prohibited (kinetic inhibition). As the precipitation of a hydrogenated carbon compound requires a higher hydrogen activity, its formation predicted after the serpentinization reaction significantly progresses (i.e. $>70 \%$ complete), similarly to the classical serpentinization degree attained in oceanic peridotites (e.g. Andreani et al. ${ }^{133}$ ).

\subsection{Summary}

According to natural, experimental, and theoretical results, the accumulation of $\mathrm{CM}$ within mantle-derived rocks of the oceanic lithosphere seems a very likely process, yet it is poorly considered during hydrothermalism. Even if CM formation under such conditions has been largely unexplored experimentally compared to volatile products, this outcome fits well with recent models that restrict $\mathrm{CH}_{4}$ formation to high-T processes $\left(>400^{\circ} \mathrm{C}\right)$ at depth, leaving open the possibility for various metastable carbon phases to form at shallower levels. Although the total amount of abiotic $\mathrm{CM}$ is not quantified yet, and might represent a small fraction of the TOC contained in the present-day oceanic lithosphere, a better understanding of its formation mechanisms, nature, and reactivity is of prime importance.

The large range of aspects, structural orders, and compositions of the CM trapped within rock textures, ranging from stable graphite usually at high $\mathrm{T}\left(>\sim 500^{\circ} \mathrm{C}\right)$ to variably ordered, hydrogenated, O-, N- and S-bearing materials and PAHs, attest to the lithosphere's organic wealth available for evolved chemical reactions and ecosystem development. The structure and functions of ecosystems inhabiting the shallow levels of the oceanic lithosphere indeed suggest that despite the general thought that $\mathrm{CH}_{4}$ or inorganic carbon species represent the main sustainable feedstocks of carbon in those settings, they 
may not be the main sources of carbon for microorganisms that rather use formate ${ }^{134}$ or more diverse abiotic organic compounds, including PAHs. ${ }^{135-137}$ The variety of organic compounds reflects the characteristics of natural systems, which are dynamic and highly heterogeneous chemically, structurally, and hydrodynamically, therefore creating chemical and redox gradients that are able to drive metastable reactions over a wide range of physicochemical conditions. They also provide various mineral substrates that have been shown to facilitate $\mathrm{CM}$ accumulations and likely further transformation. Whether minerals can affect the nature and crystallinity of the CM remains to be addressed. According to the very different crystallo-chemistry and surface properties of mineral families, different types of organic compounds may even be expected within different mineral substrates, rendering them as micro-factories with high specificity as observed in natural serpentinites. ${ }^{55}$

Observations force us to consider natural rocks as being built up of several far-fromequilibrium microenvironments that are expected to evolve with time and system fluctuations $\left(f \mathrm{H}_{2}, \mathrm{P}, \mathrm{T}, \mathrm{pH}\right.$, and fluid transport and chemistry), each offering at a given stage a specific mineral assemblage and chemical conditions that are propitious to a given series of reactions. They considerably deviate from static, buffered, bulk mineral assemblages undergoing interactions with fluids near equilibrium, as is often considered. Such microenvironments may be the locations of organic reactions simply succeeding each other or competing together, but also inorganic reactions such as carbonate precipitation and biological activity, depending on the alteration history and fluid paths. Indeed, the oceanic crust is subjected to a progressive and multistage evolution of its organic pool, including both abiotic reactions and multiple recolonizations, all along the way from ridge to subduction, hence modifying the initial signature of a compound of interest.

We attempted to summarize the main stages of abiotic carbon processing in a heterogeneous oceanic lithosphere (Figure 15.6a) from deep to shallow levels in the sketch of Figure 15.6. We recommend going beyond the formation of $\mathrm{CH}_{4}$ and the FTT reaction by considering the heterogeneity and multistage character of the system at all scales. First, CM (or graphite) can directly precipitate on fresh mineral surfaces and in vesicles during cooling and re-speciation of $\mathrm{CO}_{2}$-rich magmatic fluids at depth $\left(>400^{\circ} \mathrm{C}\right.$ and up to $800^{\circ} \mathrm{C}^{123}$ ). Fluids can also get trapped within fluid inclusions that display $\mathrm{C}_{1}-\mathrm{C}_{3} n$-alkanes initially in the fluid or formed in situ and CM (or graphite) formed in situ (see Section 15.2.3), possibly helped by subsequent retrograde reactions (stage 1, Figure 15.6b). Then, provided relatively low $\mathrm{fO}_{2}$ is available, $\mathrm{CM}$ can continue to form at $\leq 400^{\circ} \mathrm{C}$ (stages 2 and 3 , Figure 15.6b) among the new mineral assemblage from aqueous C-bearing hydrothermal fluids (magmatic or seawater derived) thought to carry a large variety of organic and inorganic carbon species formed at deeper lithospheric levels (see Sections 15.2.2 and 15.3.2). The strongest thermodynamic drive for the formation of most metastable organic molecules (see Section 15.3.4), including $n$-alkanes, organic acids, and PAHs, is below $200^{\circ} \mathrm{C}$ (stage 3, Figure 15.6b) for typical redox conditions occurring in the mafic component of the lithosphere (near the PPM buffer). In the dominant ultramafic component, conditions should be far more favorable to the abiotic formation of metastable products, and extending to higher temperatures (at least $300^{\circ} \mathrm{C}$ at the QFM buffer). Indeed, 

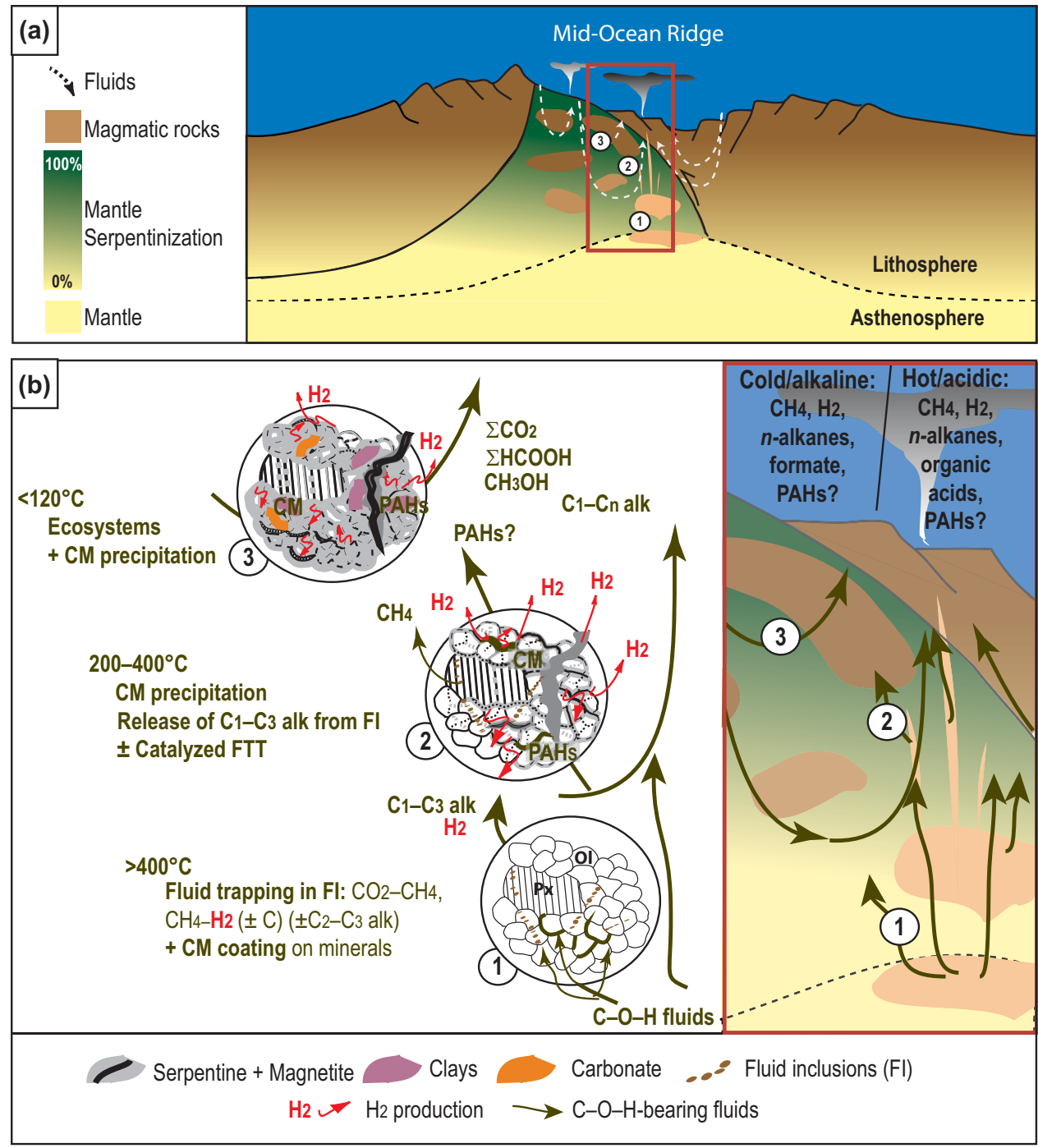

Figure 15.6 Sketch depicting the main stages of carbon processing in the oceanic lithosphere during the multistage fluid-rock reactions ${ }^{133}$ recorded in such dynamic systems. (a) Geologic setting of a slow-spreading ridge where mantle is tectonically exhumed, simultaneously with localized and ephemeral magmatic injections. These environments appear to be the most favorable ones for abiotic organic synthesis according to the available natural observations, experiments, and thermodynamic calculations. (b) Summary of the three main stages of carbon processing in a column of the oceanic lithosphere shown in (a), illustrated through a magnification of the mantle rock textures along with the hypothetical nature of the percolating fluids. See the text for details. alk = alkanes. 
serpentinization provides high levels of $\mathrm{H}_{2}$ over a wide range of $\mathrm{T}$ and $\mathrm{pH}$ conditions $\left(100^{\circ} \mathrm{C}, \mathrm{pH} 9 \text { to } 350^{\circ} \mathrm{C}, \mathrm{pH} 3\right)^{13,102}$ that favors reduction reactions while providing variable single-carbon reactants in the fluid, especially at low $\mathrm{T}<\sim 200^{\circ} \mathrm{C}\left(\Sigma \mathrm{CO}_{2}, \Sigma \mathrm{HCOOH}\right.$, methanol). ${ }^{101} \mathrm{~A}$ body of experimental work has shown that the most efficient production of $\mathrm{H}_{2}$ from serpentinization occurs at $\sim 300^{\circ} \mathrm{C}$, notably with modified seawater after interaction with magmatic lithologies. ${ }^{138,139}$ Alteration of ultramafic rocks also releases specific transition metals such as $\mathrm{Fe}$ and $\mathrm{Ni}$ and is known to change sulfur speciation, leading to the formation of potential metallic-sulfide catalysts. ${ }^{140,141}$ The $f \mathrm{H}_{2}$ of those systems can be highly variable down to the micrometer scale, ranging from QFM buffer conditions in magnetite-dominated domains to $\mathrm{fH}_{2}$ values of several orders of magnitude higher to form $\mathrm{Fe}-\mathrm{Ni}$ alloys such as awaruite near serpentinization fronts. ${ }^{141}$ Serpentinization is also characterized by the abundant formation of phyllosilicates, oxides, and hydroxides that are thought to facilitate $\mathrm{CM}$ precipitation, condensation, and transformation (stages 2 and 3 , Figure 15.6b). The ephemeral magmatic activity associated with mantle-rock exhumation in a slow-spreading environment (Figure 15.6) may also drive fluctuating $\mathrm{T}$ or $\mathrm{pH}$ conditions and $\mathrm{C}-\mathrm{O}-\mathrm{H}$ fluid inputs. This can shift the local thermal regime from a coldalkaline to a hot-acidic environment, and vice versa, as observed at the Rainbow massif. ${ }^{142}$ The tectono-magmatic activity near the ridge axis also affects transport processes that control the fluid residence time in the system, a determinant of $\mathrm{C}-\mathrm{O}-\mathrm{H}$ fluid speciation, especially at low T. ${ }^{101}$

\subsection{Limits to Knowledge and Unknowns}

To achieve a better understanding of the mechanisms and processes leading to the abiotic formation of $\mathrm{CM}$ in the oceanic lithosphere and to carbon cycling under those environments in general, one of the major challenges future studies will have to face is to improve criteria for establishing the origin of organic carbon accumulations found within the habitable oceanic rocks. As highlighted in this chapter, graphitic compounds occur from deep levels where solely abiotic reactions can account for their generation, up to colonizable depths, where $\mathrm{H}_{2}$ and abiotic organic compounds are valuable sources of energy and carbon for microbial communities ${ }^{27,143}$ below the $\mathrm{T}$ limit of life currently established at $122^{\circ} \mathrm{C}^{144}$ This deep life indeed has the ability to capitalize on the steady stream of both inorganic and organic serpentinization by-products, converting $\mathrm{C}$ into biomass and competing against abiotic reactions of $\mathrm{C}$ reduction. ${ }^{23}$ These rock-hosted microbial ecosystems, along with the photosynthesis-derived organic compounds contained in seawater and injected into the hydrothermal conduits, experience hydrothermal degradation and can be transformed, similarly to sedimentary organic matter, into a kerogen-like or bitumen-like macromolecular material ${ }^{18,19,31}$ with structural and chemical similarities with the hydrothermally formed CM. Up to now, more attention has been paid to CM in meteorites ${ }^{145}$ than in hard rock samples from Earth's lithosphere. Meteorites testify to the capacity of hydrothermal activity to drive complex abiotic organic synthesis. 
Identifying CM origins will have to go through more systematic CM characterization in rocks from various geological settings. This may also contribute to the identification of new organic minerals (see mineralchallenge.net).

The role (in terms of kinetics and selectivity) of mineral phases in organic synthesis, particularly in CM formation, evolution, and preservation, should be a prime direction for future research, too. New experimental work is required in which minerals should be introduced and carefully characterized to possibly identify $\mathrm{CM}$, which has been neglected so far, along with its reactivity and formation mechanisms. We encourage a more systematic investigation of the liquids, gases, and solids altogether in future hydrothermal experiments in order to unravel possible genetic relationships and to determine their respective roles in the organic synthesis factory.

Tracking reactions in situ in both natural and experimental solids requires maintaining the ongoing effort to develop microscale to nanoscale investigation methods and to identify biotic/abiotic criteria for use both in natural samples and in experiments that will have to face contamination issues. As detailed in Section 15.2, most of the evidence for CM abiogenicity was derived from the mineral assemblages and textural relationships between CM and mineral phases. Compared to bulk analysis, microscale characterization using high-resolution imaging techniques will allow a comprehensive description of the textural context in which organic carbon occurs and will provide constraints regarding whether or not the carbon compounds are indigeneous. ${ }^{145}$ Microscale techniques can also capture the co-occurrence and relationships of $\mathrm{CM}$ with metals and minerals, and are thus particularly well suited to tracking organic matter production, evolution, and transport within the oceanic lithosphere.

\section{Acknowledgments}

The authors want to thank the Deep Carbon Observatory, the French CNRS (INSU, PIE, EPOV, and MITI Défi Origines programs), and the French National Research Agency (ANR-14-CE01-0008) for funding. This chapter is also the result of numerous fruitful discussions with several partners, notably the participants of the deepOASES project (PI B. Ménez).

\section{Questions for the Classroom}

1 Why is it important to better constrain the abiotic organic reactions on Earth?

2 Which impact (if any) could abiotic organic synthesis have on Earth today and have had in the past?

3 What is the main message of this chapter and what do you think of it?

4 Why is the oceanic lithosphere a propitious place to investigate abiotic organic synthesis?

5 Which other settings on Earth would be of interest, as well as elsewhere in the solar system? What would be the implications? 
6 Which organic compounds are thermodynamically stable? How and why can metastable organic compounds be formed and subsist through time in rocks?

7 What are the main abiotic organic compounds formed through the hydrothermal alteration of the oceanic lithosphere? How do they vary as a function of temperature? What are the other important parameters?

8 What are the strengths of micro-imaging and in situ micro-spectroscopic approaches for unraveling the reaction paths leading to abiotic organic synthesis in rocks?

9 Can you think of potential markers for discriminating between the abiotic and biologic origins of carbonaceous compounds in rocks? Can they be addressed with available techniques of analyses or do they require technological development?

\section{References}

1. McCollom, T. M. Laboratory simulations of abiotic hydrocarbon formation in Earth's deep subsurface. In: Carbon in Earth. Reviews in Mineralogy \& Geochemistry, Vol. 75 (eds. R. M. Hazen, A. P. Jones \& J. A. Baross), 467-494 (Mineralogical Society of America, 2013).

2. Sephton, M. A. \& Hazen, R. M. On the origins of deep hydrocarbons. In: Carbon in Earth. Reviews in Mineralogy \& Geochemistry, Vol. 75 (eds. R. M. Hazen, A. P. Jones \& J. A. Baross), 449-465 (Mineralogical Society of America, 2013).

3. Etiope, G. \& Sherwood Lollar, B. Abiotic methane on Earth. Rev Geophys 51, 276-299 (2013).

4. Proskurowski, G. et al. Abiogenic hydrocarbon production at Lost City hydrothermal field. Science 319, 604-607 (2008).

5. Haggerty, J. A. \& Fisher, J. B. Short-chain organic acids in interstitial waters from Mariana and Bonin forearc serpentines: Leg 125. In: Proceedings of the Ocean Drilling Program, Vol. 125 (eds. P. Fryer, J. A. Pearce \& L. B. Stokking), 387-395 (Ocean Drilling Program, 1992).

6. McCollom, T. M. \& Seewald, J. S. Abiotic synthesis of organic compounds in deepsea hydrothermal environments. Chem Rev 107, 382-401 (2007).

7. Wang, D. T., Reeves, E. P., McDermott, J. M., Seewald, J. S. \& Ono, S. Clumped isotopologue constraints on the origin of methane at seafloor hot springs. Geochim Cosmochim Acta 223, 141-158 (2018).

8. McDermott, J. M., Seewald, J. S., German, C. R. \& Sylva, S. P. Pathways for abiotic organic synthesis at submarine hydrothermal fields. Proc Natl Acad Sci USA 112, 7668-7672 (2015).

9. Kelley, D. S. Methane-rich fluids in the oceanic crust. J Geophys Res 101, 2943-2962 (1996).

10. Kelley, D. S. \& Früh-Green, G. L. Abiogenic methane in deep-seated mid-ocean ridge environments: insights from stable isotope analyses. J Geophys Res 104, 10439-10460 (1999).

11. Etiope, G. et al. Widespread abiotic methane in chromitites. Sci Rep 8, 8728 (2018).

12. Etiope, G. Methane origin in the Samail ophiolite: comment on "Modern water/rock reactions in Oman hyperalkaline peridotite aquifers and implications for microbial habitability". Geochim Cosmochim Acta 197, 467-470 (2017). 
13. Miller, H. M. et al. Modern water/rock reactions in Oman hyperalkaline peridotite aquifers and implications for microbial habitability. Geochim Cosmochim Acta 179, 217-241 (2016).

14. McCollom, T. M. \& Seewald, J. S. A reassessment of the potential for reduction of dissolved $\mathrm{CO}_{2}$ to hydrocarbons during serpentinization of olivine. Geochim Cosmochim Acta 65, 3769-3778 (2001).

15. McCollom, T. M. \& Seewald, J. S. Experimental constraints on the hydrothermal reactivity of organic acids and acid anions: I. Formic acid and formate. Geochim Cosmochim Acta 67, 3625-3644 (2003).

16. Lang, S. Q., Butterfield, D. A., Schulte, M., Kelley, D. S. \& Lilley, M. D. Elevated concentrations of formate, acetate and dissolved organic carbon found at the Lost City hydrothermal field. Geochim Cosmochim Acta 74, 941-952 (2010).

17. Holm, N. G. \& Charlou, J. L. Initial indications of abiotic formation of hydrocarbons in the Rainbow ultramafic hydrothermal system, Mid-Atlantic Ridge. Earth Planet Sci Lett 191, 1-8 (2001).

18. Simoneit, B. R. T., Lein, A. Y., Peresypkin, V. I. \& Osipov, G. A. Composition and origin of hydrothermal petroleum and associated lipids in the sulfide deposits of the Rainbow field (Mid-Atlantic Ridge at $36^{\circ} \mathrm{N}$ ). Geochim Cosmochim Acta 68, 2275-2294 (2004).

19. Konn, C. et al. Hydrocarbons and oxidized organic compounds in hydrothermal fluids from Rainbow and Lost City ultramafic-hosted vents. Chem Geol 258, 299-314 (2009).

20. Konn, C., Charlou, J. L., Holm, N. G. \& Mousis, O. The production of methane, hydrogen, and organic compounds in ultramafic-hosted hydrothermal vents of the Mid-Atlantic Ridge. Astrobiology 15, 381-399 (2015).

21. Reeves, E. P., McDermott, J. M. \& Seewald, J. S. The origin of methanethiol in midocean ridge hydrothermal fluids. Proc Natl Acad Sci USA 111, 5474-5479 (2014).

22. McCollom, T. M., Seewald, J. S. \& German, C. R. Investigation of extractable organic compounds in deep-sea hydrothermal vent fluids along the Mid-Atlantic Ridge. Geochim Cosmochim Acta 156, 122-144 (2015).

23. Lang, S. Q. et al. Microbial utilization of abiogenic carbon and hydrogen in a serpentinite-hosted system. Geochim Cosmochim Acta 92, 82-99 (2012).

24. Lang, S. Q., Frûh-Green, G. L., Bernasconi, S. M. \& Butterfield, D. A. Sources of organic nitrogen at the serpentinite-hosted Lost City hydrothermal field. Geobiology 11, 154-169 (2013).

25. Alt, J. C. et al. Uptake of carbon and sulfur during seafloor serpentinization and the effects of subduction metamorphism in Ligurian peridotites. Chem Geol 322-323, 268-277 (2012).

26. Delacour, A., Früh-Green, G. L., Bernasconi, S. M., Schaeffer, P. \& Kelley, D. S. Carbon geochemistry of serpentinites in the Lost City hydrothermal system $\left(30^{\circ} \mathrm{N}\right.$, MAR). Geochim Cosmochim Acta 72, 3681-3702 (2008).

27. Früh-Green, G. L., Connolly, J. A. D., Plas, A., Kelley, D. S. \& Grobety, B. Serpentinization of oceanic peridotites: implications for geochemical cycles and biological activity. In: The Subseafloor Biosphere at Mid-Ocean Ridges, Vol. 144, Geophysical Monograph Series (eds. W. S. D. Wilcock et al.), 119-136 (American Geophysical Union, 2004).

28. Schwarzenbach, E. M., Früh-Green, G. L., Bernasconi, S. M., Alt, J. C. \& Plas, A. Serpentinization and carbon sequestration: a study of two ancient peridotite-hosted hydrothermal systems. Chem Geol 351, 115-133 (2013). 
29. Klein, F. et al. Fluid mixing and the deep biosphere of a fossil Lost City-type hydrothermal system at the Iberia Margin. Proc Natl Acad Sci USA 112, 12036-12041 (2015).

30. Ménez, B., Pasini, V. \& Brunelli, D. Life in the hydrated suboceanic mantle. Nat Geosci 5, 133-137 (2012).

31. Pasini, V. et al. Low temperature hydrothermal oil and associated biological precursors in serpentinites from Mid-Ocean Ridge. Lithos 178, 84-95 (2013).

32. Amend, J. P., LaRowe, D. E., McCollom, T. M. \& Shock, E. L. The energetics of organic synthesis inside and outside the cell. Philos Trans R Soc Lond B Biol Sci 368, 20120255 (2013).

33. Milesi, V., McCollom, T. M. \& Guyot, F. Thermodynamic constraints on the formation of condensed carbon from serpentinization fluids. Geochim Cosmochim Acta 189, 391-403 (2016).

34. Shipp, J. et al. Organic functional group transformations in water at elevated temperature and pressure: reversibility, reactivity, and mechanisms. Geochim Cosmochim Acta 104, 194-209 (2013).

35. Shock, E. L. Geochemical constraints on the origin of organic compounds in hydrothermal systems. Origins Life Evol Biosphere 20, 331-367 (1990).

36. Rumble, D. Hydrothermal graphitic carbon. Elements 10, 427-433 (2014).

37. Zubkov, V. S. Tendencies in the distribution and hypotheses of the genesis of condensed naphthides in magmatic rocks from various geodynamic environments. Geochem Int 47, 741-757 (2009).

38. Pikovskii, Y. I., Chernova, T. G., Alekseeva, T. A. \& Verkhovskaya, Z. I. Composition and nature of hydrocarbons in modern serpentinization areas in the ocean. Geochem Int 42, 971-976 (2004).

39. Echigo, T. \& Kimata, M. Crystal chemistry and genesis of organic minerals: a review of oxalate and polycyclic aromatic hydrocarbon minerals. Can Mineral 48, 1329-1357 (2010).

40. Stein, S. On the high temperature chemical equilibria of polycyclic aromatic hydrocarbons. J Phys Chem 82, 566-571 (1978).

41. Murdoch, J. Pendletonite, a new hydrocarbon mineral from California. Am Mineral 52, 611-616 (1967).

42. Echigo, T., Kimata, M. \& Maruoka, T. Crystal-chemical and carbon-isotopic characteristics of karpatite $\left(\mathrm{C}_{24} \mathrm{H}_{12}\right)$ from the Picacho Peak Area, San Benito County, California: evidences for the hydrothermal formation. Am Mineral 92, 1262-1269 (2007).

43. Simoneit, B. R. T. \& Lonsdale, P. F. Hydrothermal petroleum in mineralized mounds at the seabed of Guaymas Basin. Nature 295, 198 (1982).

44. Zolotov, M. \& Shock, E. Abiotic synthesis of polycyclic aromatic hydrocarbons on Mars. J Geophys Res 104, 14033-14049 (1999).

45. Zolotov, M. Y. \& Shock, E. L. A thermodynamic assessment of the potential synthesis of condensed hydrocarbons during cooling and dilution of volcanic gases. J Geophys Res 105, 539-559 (2000).

46. Potticary, J., Jensen, T. T. \& Hall, S. R. Nanostructural origin of blue fluorescence in the mineral karpatite. Sci Rep 7, 9867 (2017).

47. Ciliberto, E. et al. Aliphatic hydrocarbons in metasomatized gabbroic xenoliths from Hyblean diatremes (Sicily): genesis in a serpentinite hydrothermal system. Chem Geol 258, 258-268 (2009). 
48. Piotrovskii, G. L. Karpatite (carpathite) - a new organic mineral from Transcarpathia. Lvov Geol Obs Miner Sb 9, 120-127 (1955).

49. Strunz, H. \& Contag, B. Evenkite, flagstaffite, idrialite, and refikite. Neu Jb Mineral, Mh 1, 19-25 (1965).

50. Rost, R. The minerals in the burning shafts at Kladno. Ceská Ákad Rozpravky 11, 1-19 (1937).

51. Foresti, E. \& Riva di Sanseverino, L. X-ray crystal and molecular structure of an organic mineral: simonellite, $\mathrm{C}_{19} \mathrm{H}_{24}$. Atti Accad Naz Lincei 47, 41-54 (1969).

52. Skropyshev, A. V. A paraffin in a polymetallic vein. Dokl Akad Nauk SSSR 88, 717-719 (1953).

53. Bassez, M.-P., Takano, Y. \& Ohkouchi, N. Organic analysis of peridotite rocks from the Ashadze and Logatchev hydrothermal sites. Int J Mol Sci 10, 2986-2998 (2009).

54. Mateeva, T. et al. Preserved organic matter in a fossil ocean continent transition in the Alps: the example of Totalp, SE Switzerland. Swiss J Geosci 110, 457-478 (2017).

55. Sforna, M. C. et al. Abiotic formation of condensed carbonaceous matter in the hydrating oceanic crust. Nat Commun 9, 5049 (2018).

56. Ménez, B. et al. Mineralizations and transition metal mobility driven by organic carbon during low-temperature serpentinization. Lithos 323, 262-276 (2018).

57. Scribano, V., Sapienza, G., Braga, R. \& Morten, L. Gabbroic xenoliths in tuffbreccia pipes from the Hyblean Plateau: insights into the nature and composition of the lower crust underneath South-eastern Sicily, Italy. Miner Petrol 86, 63-88 (2006).

58. Scirè, S. et al. Asphaltene-bearing mantle xenoliths from Hyblean diatremes, Sicily. Lithos 125, 956-968 (2011).

59. Mathez, E. A. Carbonaceous matter in mantle xenoliths: composition and relevance to the isotopes. Geochim Cosmochim Acta 51, 2339-2347 (1987).

60. Mathez, E. A. \& Delaney, J. R. The nature and distribution of carbon in submarine basalts and peridotite nodules. Earth Planet Sci Lett 56, 217-232 (1981).

61. Mathez, E. A., Dietrich, V. J. \& Irving, A. J. The geochemistry of carbon in mantle peridotites. Geochim Cosmochim Acta 48, 1849-1859 (1984).

62. Tingle, T. N., Mathez, E. A. \& Michael, F. H. Carbonaceous matter in peridotites and basalts studied by XPS, SALI, and LEED. Geochim Cosmochim Acta 55, 1345-1352 (1991).

63. Muenow, D. W. High temperature mass spectrometric gas-release studies of Hawaiian volcanic glass: Pele's tears. Geochim Cosmochim Acta 37, 1551-1561 (1973).

64. Andreani, M., Munoz, M., Marcaillou, C. \& Delacour, A. $\mu$ XANES study of iron redox state in serpentine during oceanic serpentinization. Lithos 178, 70-83 (2013).

65. Klein, F. et al. Magnetite in seafloor serpentinite - some like it hot. Geology 42, 135-138 (2014).

66. Plümper, O., Beinlich, A., Bach, W., Janots, E. \& Austrheim, H. Garnets within geode-like serpentinite veins: implications for element transport, hydrogen production and life-supporting environment formation. Geochim Cosmochim Acta 141, 454-471 (2014).

67. Mayhew, L. E., Ellison, E. T., McCollom, T. M., Trainor, T. P. \& Templeton, A. S. Hydrogen generation from low-temperature water-rock reactions. Nat Geosci 6, 478-484 (2013). 
68. Manuella, F. C., Carbone, S. \& Barreca, G. Origin of saponite-rich clays in a fossil serpentinite-hosted hydrothermal system in the crustal basement of the Hyblean Plateau (Sicily, Italy). Clays Clay Miner 60, 18-31 (2012).

69. Pizzarello, S., Cooper, G. W. \& Flynn, G. J. The nature and distribution of the organic material in carbonaceous chondrites and interplanetary dust particles. In: Meteorites and the Early Solar System II (eds. D. S. Lauretta \& H. Y. McSween Jr.), 625-651 (University of Arizona Press, 2006).

70. Le Guillou, C. \& Brearley, A. Relationships between organics, water and early stages of aqueous alteration in the pristine CR3.0 chondrite MET 00426. Geochim Cosmochim Acta 131, 344-367 (2014).

71. Pearson, V. K. et al. Clay mineral-organic matter relationships in the early solar system. Meteorit Planet Sci 37, 1829-1833 (2002).

72. Zega, T. J. et al. Mineral associations and character of isotopically anomalous organic material in the Tagish Lake carbonaceous chondrite. Geochim Cosmochim Acta 74, 5966-5983 (2010).

73. Pisapia, C., Jamme, F., Duponchel, L. \& Ménez, B. Tracking hidden organic carbon in rocks using chemometrics and hyperspectral imaging. Sci Rep 8, 2396 (2018).

74. Kelley, D. S. \& Früh-Green, G. L. Volatile lines of descent in submarine plutonic environments: insights from stable isotope and fluid inclusion analyses. Geochim Cosmochim Acta 65, 3325-3346 (2001).

75. Sachan, H. K., Mukherjee, B. K. \& Bodnar, R. J. Preservation of methane generated during serpentinization of upper mantle rocks: evidence from fluid inclusions in the Nidar ophiolite, Indus Suture Zone, Ladakh (India). Earth Planet Sci Lett 257, 47-59 (2007).

76. Vanko, D. A. \& Stakes, D. S. Fluids in oceanic layer 3: evidence from veined rocks, Hole 735B, Southwest Indian Ridge. In: Proceeding of the Ocean Drilling Program, Vol. 118 (eds. R. P. V. Herzen, R. P. Fox, A. Palmer \& P. T. Robinson), 181-215 (Ocean Drilling Program, 1997).

77. Kelley, D. S. Fluid evolution in slow-spreading environments. In: Proceeding of the Ocean Drilling Program, Vol. 153 (eds. J. A. Karson, M. Cannat, D. J. Miller \& D. Elthon), 399-415 (Ocean Drilling Program, 1997).

78. Bortnikov, N. S. et al. The Rainbow serpentinite-related hydrothermal field, MidAtlantic Ridge, $36^{\circ} 14^{\prime} \mathrm{N}$ : mineralogical and geochemical features. In: Mineral Deposits at the Beginning of the 21st Century (eds. A. Piestrzyhski et al.), 265-268 (Swets \& Zeitlinger Publishers Lisse, 2001).

79. Elthon, D. Petrology of gabbroic rocks from the Mid-Cayman Rise Spreading Center. J Geophys Res 92, 658-682 (1987).

80. Nakamura, K. et al. Serpentinized troctolites exposed near the Kairei hydrothermal field, Central Indian Ridge: insights into the origin of the Kairei hydrothermal fluid supporting a unique microbial ecosystem. Earth Planet Sci Lett 280, 128-136 (2009).

81. Katayama, I., Kurosaki, I. \& Hirauchi, K.-I. Low silica activity for hydrogen generation during serpentinization: an example of natural serpentinites in the Mineoka ophiolite complex, central Japan. Earth Planet Sci Lett 298, 199-204 (2010).

82. Miura, M., Arai, S. \& Mizukami, T. Raman spectroscopy of hydrous inclusions in olivine and orthopyroxene in ophiolitic harzburgite: implications for elementary processes in serpentinization. J Miner Petrol Sci 106, 91-96 (2011). 
83. Kelley, D. S., Gillis, K. M. \& Thompson, G. Fluid evolution in submarine magmahydrothermal systems at the Mid-Atlantic Ridge. J Geophys Res 98, 19579-19596 (1993).

84. Holloway, J. R. \& O'Day, P. A. Production of $\mathrm{CO}_{2}$ and $\mathrm{H}_{2}$ by diking-eruptive events at mid-ocean ridges: implications for abiotic organic synthesis and global geochemical cycling. Int Geol Rev 42, 673-683 (2000).

85. Luque, F. J. et al. Deposition of highly crystalline graphite from moderatetemperature fluids. Geology 37, 275-278 (2009).

86. Pasteris, J. D. Occurrence of graphite in serpentinized olivines in kimberlite. Geology 9, 356-359 (1981).

87. Pasteris, J. D. \& Chou, I. M. Fluid-deposited graphitic inclusions in quartz: comparison between KTB (German Continental Deep-Drilling) core samples and artificially reequilibrated natural inclusions,. Geochim Cosmochim Acta 62, 109-122 (1998).

88. Satish-Kumar, M. Graphite-bearing $\mathrm{CO}_{2}$-fluid inclusions in granulites: insights on graphite precipitation and carbon isotope evolution. Geochim Cosmochim Acta 69 , 3841-3856 (2005).

89. Wopenka, B. \& Pasteris, J. D. Structural characterization of kerogens to granulitefacies graphite: applicability of Raman microprobe spectroscopy. Am Mineral 78, 533-557 (1993).

90. Beny-Bassez, C. \& Rouzaud, J. N. Characterization of carbonaceous materials by correlated electron and optical microscopy and Raman microscopy. In: Scanning Electron Microscopy, 119-132 (SEM Inc., 1985).

91. Beyssac, O. \& Rumble, D. Graphitic carbon: a ubiquitous, diverse, and useful geomaterial. Elements 10, 415-420 (2014).

92. Shipp, J., Gould, I. R., Shock, E. L., Williams, L. B. \& Hartnett, H. E. Sphalerite is a geochemical catalyst for carbon-hydrogen bond activation. Proc Natl Acad Sci USA 111, 11642-11645 (2014).

93. Venturi, S. et al. Mineral-assisted production of benzene under hydrothermal conditions: insights from experimental studies on $\mathrm{C}_{6}$ cyclic hydrocarbons. $J$ Volcanol Geothermal Res 346, 21-27 (2017).

94. Yang, Z., Gould, I. R., Williams, L. B., Hartnett, H. E. \& Shock, E. L. Effects of ironcontaining minerals on hydrothermal reactions of ketones. Geochim Cosmochim Acta 223, 107-126 (2018).

95. Voglesonger, K. M., Holloway, J. R., Dunn, E. E., Dalla-Betta, P. J. \& O’Day, P. A. Experimental abiotic synthesis of methanol in seafloor hydrothermal systems during diking events. Chem Geol 180, 129-139 (2001).

96. McCollom, T. M. \& Seewald, J. S. Abiotic formation of hydrocarbons and oxygenated compounds during thermal decomposition of iron oxalate. Origins Life Evol Biosphere 29, 167-186 (1999).

97. Chen, Y., Li, C. W. \& Kanan, M. W. Aqueous $\mathrm{CO}_{2}$ reduction at very low overpotential on oxide-derived Au nanoparticles. J Am Chem Soc 134, 19969-19972 (2012).

98. Liu, M. et al. Enhanced electrocatalytic $\mathrm{CO}_{2}$ reduction via field-induced reagent concentration. Nature 537, 382-386 (2016).

99. Marcaillou, C., Munoz, M., Vidal, O., Parra, T. \& Harfouche, M. Mineralogical evidence for $\mathrm{H}_{2}$ degassing during serpentinization at $300^{\circ} \mathrm{C} / 300$ bar. Earth Planet Sci Lett 303, 281-290 (2011).

100. Chou, I. M. Permeability of precious metals to hydrogen at $2 \mathrm{~kb}$ total pressure and elevated temperatures. Am J Sci 286, 638-658 (1986). 
101. Seewald, J. S., Zolotov, M. Y. \& McCollom, T. M. Experimental investigation of single carbon compounds under hydrothermal conditions. Geochim Cosmochim Acta 70, 446-460 (2006).

102. Fouquet, Y. et al. Geodiversity of hydrothermal processes along the Mid-Atlantic ridge and ultramafic-hosted mineralization: a new type of oceanic $\mathrm{Cu}-\mathrm{Zn}-\mathrm{Co}-\mathrm{Au}$ volcanogenic massive sulfide deposit. In: Diversity of Hydrothermal Systems on Slow Spreading Ocean Ridges, Vol. 188, Geophysical Monograph Series (eds. P. Rona, C. Devey, J. Dyment \& B. Murton), 321-367 (American Geophysical Union, 2010).

103. Williams, L. B., Canfield, B., Voglesonger, K. M. \& Holloway, J. R. Organic molecules formed in a "primordial womb". Geology 33, 913-916 (2005).

104. Horita, J. \& Berndt, M. E. Abiogenic methane formation and isotopic fractionation under hydrothermal conditions. Science 285, 1055-1057 (1999).

105. Ji, F., Zhou, H. \& Yang, Q. The abiotic formation of hydrocarbons from dissolved $\mathrm{CO}_{2}$ under hydrothermal conditions with cobalt-bearing magnetite. Origins Life Evol Biosphere 38, 117-125 (2008).

106. McCollom, T. M. Abiotic methane formation during experimental serpentinization of olivine. Proc Natl Acad Sci USA 113, 13965-13970 (2016).

107. Oze, C., Jones, L. C., Goldsmith, J. I. \& Rosenbauer, R. J. Differentiating biotic from abiotic methane genesis in hydrothermally active planetary surfaces. Proc Natl Acad Sci USA 109, 9750-9754 (2012).

108. Lang, S. Q. et al. $\mathrm{H}_{2} / \mathrm{CH}_{4}$ ratios cannot reliably distinguish abiotic vs. biotic methane in natural hydrothermal systems. Proc Natl Acad Sci USA 109, E3210-E3210 (2012).

109. Huang, R. et al. The $\mathrm{H}_{2} / \mathrm{CH}_{4}$ ratio during serpentinization cannot reliably identify biological signatures. Sci Rep 6, 33821 (2016).

110. Lazar, C., Cody, G. D. \& Davis, J. M. A kinetic pressure effect on the experimental abiotic reduction of aqueous $\mathrm{CO}_{2}$ to methane from 1 to $3.5 \mathrm{kbar}$ at $300^{\circ} \mathrm{C}$. Geochim Cosmochim Acta 151, 34-48 (2015).

111. Hellevang, H., Huang, S. \& Thorseth, I. H. The potential for low-temperature abiotic hydrogen generation and a hydrogen-driven deep biosphere. Astrobiology 11, 711-724 (2011).

112. Neubeck, A., Duc, N. T., Bastviken, D., Crill, P. \& Holm, N. G. Formation of $\mathrm{H}_{2}$ and $\mathrm{CH}_{4}$ by weathering of olivine at temperatures between 30 and $70^{\circ} \mathrm{C}$. Geochem Trans 12, 6 (2011).

113. Neubeck, A. et al. Olivine alteration and $\mathrm{H}_{2}$ production in carbonate-rich, low temperature aqueous environments. Planet Space Sci 96, 51-61 (2014).

114. Neubeck, A., Nguyen, D. T. \& Etiope, G. Low-temperature dunite hydration: evaluating $\mathrm{CH}_{4}$ and $\mathrm{H}_{2}$ production from $\mathrm{H}_{2} \mathrm{O}$ and $\mathrm{CO}_{2}$. Geofluids 16, 408-420 (2016).

115. McCollom, T. M. \& Donaldson, C. Generation of hydrogen and methane during experimental low-temperature reaction of ultramafic rocks with water. Astrobiology 16, 389-406 (2016).

116. Berndt, M. E., Allen, D. E. \& Seyfried, W. E., Jr. Reduction of $\mathrm{CO}_{2}$ during serpentinization of olivine at $300^{\circ} \mathrm{C}$ and 500 bar. Geology 24, 351-354 (1996).

117. Foustoukos, D. I. \& Seyfried, W. E. Hydrocarbons in hydrothermal vent fluids: the role of chromium-bearing catalysts. Science 304, 1002-1005 (2004).

118. Fu, Q., Sherwood Lollar, B., Horita, J., Lacrampe-Couloume, G. \& Seyfried, W. E. Abiotic formation of hydrocarbons under hydrothermal conditions: constraints from chemical and isotope data. Geochim Cosmochim Acta 71, 1982-1998 (2007). 
119. Lazar, C., McCollom, T. M. \& Manning, C. E. Abiogenic methanogenesis during experimental komatiite serpentinization: implications for the evolution of the early Precambrian atmosphere. Chem Geol 326-327, 102-112 (2012).

120. Etiope, G. \& Ionescu, A. Low-temperature catalytic $\mathrm{CO}_{2}$ hydrogenation with geological quantities of ruthenium: a possible abiotic $\mathrm{CH}_{4}$ source in chromitite-rich serpentinized rocks. Geofluids 15, 438-452 (2015).

121. Lu, Q. et al. A selective and efficient electrocatalyst for carbon dioxide reduction. Nat Commun 5, 3242 (2014).

122. Rushdi, A. I. \& Simoneit, B. R. T. Lipid Formation by aqueous Fischer-Tropschtype synthesis over a temperature range of $100 \mathrm{C}$ to $400 \mathrm{C}$. Origins Life Evol Biosphere 31, 103-118 (2001).

123. Tingle, T. N. \& Hochella, M. F. Formation of reduced carbonaceous matter in basalts and xenoliths: reaction of $\mathrm{C}-\mathrm{O}-\mathrm{H}$ gases on olivine crack surfaces. Geochim Cosmochim Acta 57, 3245-3249 (1993).

124. McCollom, T. M. Formation of meteorite hydrocarbons from thermal decomposition of siderite $\left(\mathrm{FeCO}_{3}\right)$. Geochim Cosmochim Acta 67, 311-317 (2003).

125. Dufaud, F., Martinez, I. \& Shilobreeva, S. Experimental study of Mg-rich silicates carbonation at 400 and $500{ }^{\circ} \mathrm{C}$ and 1 kbar. Chem Geol 265, 79-87 (2009).

126. Luquot, L., Andreani, M., Gouze, P. \& Camps, P. $\mathrm{CO}_{2}$ percolation experiment through chlorite/zeolite-rich sandstone (Pretty Hill Formation - Otway Basin Australia). Chem Geol 294-295, 75-88 (2012).

127. Milesi, V. et al. Formation of $\mathrm{CO}_{2}, \mathrm{H}_{2}$ and condensed carbon from siderite dissolution in the $200-300^{\circ} \mathrm{C}$ range and at $50 \mathrm{MPa}$. Geochim Cosmochim Acta 154, 201-211 (2015).

128. Ferry, J. M. \& Baumgartner, L. Thermodynamic models of molecular fluids at the elevated pressures and temperatures of crustal metamorphism. In: Thermodynamic Modeling of Geological Materials: Minerals, Fluids and Melts. Reviews in Mineralogy and Geochemistry, Vol. 17 (eds. I. S. E. Carmichael \& H. P. Eugster), 323-365 (Mineralogical Society of America, 1987).

129. Holloway, J. R. Graphite- $-\mathrm{CH}_{4}-\mathrm{H}_{2} \mathrm{O}-\mathrm{CO}_{2}$ equilibria at low-grade metamorphic conditions. Geology 12, 455-458 (1984).

130. Frost, B. R. Mineral equilibria involving mixed-volatiles in a $\mathrm{C}-\mathrm{O}-\mathrm{H}$ fluid phase; the stabilities of graphite and siderite. Am J Sci 279, 1033-1059 (1979).

131. McCollom, T. M. The influence of minerals on decomposition of the $n$-alkyl- $\alpha$-amino acid norvaline under hydrothermal conditions. Geochim Cosmochim Acta 104, 330-357 (2013).

132. Shock, E. L. et al. Thermodynamics of organic transformations in hydrothermal fluids. Rev Mineral Geochem 76, 311-350 (2013).

133. Andreani, M., Mével, C., Boullier, A. M. \& Escartín, J. Dynamic control on serpentine crystallization in veins: constraints on hydration processes in oceanic peridotites. Geochem Geophys Geosyst 8, Q02012 (2007).

134. Lang, S. Q. et al. Deeply-sourced formate fuels sulfate reducers but not methanogens at Lost City hydrothermal field. Sci Rep 8, 755 (2018).

135. Mason, O. U. et al. First investigation of the microbiology of the deepest layer of ocean crust. PLoS One 5, e15399 (2010).

136. Pisapia, C. et al. Mineralizing filamentous bacteria from the Prony bay hydrothermal field give new insights into the functioning of serpentinization-based subseafloor ecosystems. Front Microbiol 8, 57 (2017). 
137. Trias, R. et al. High reactivity of deep biota under anthropogenic $\mathrm{CO}_{2}$ injection into basalt. Nat Commun 8, 1063 (2017).

138. Malvoisin, B., Brunet, F., Carlut, J., Rouméjon, S. \& Cannat, M. Serpentinization of oceanic peridotites: 2. Kinetics and processes of San Carlos olivine hydrothermal alteration. J Geophys Res 117, B04102 (2012).

139. Pens, M., Andreani, M., Daniel, I., Perrillat, J.-P. \& Cardon, H. Contrasted effect of aluminum on the serpentinization rate of olivine and orthopyroxene under hydrothermal conditions. Chem Geol 441, 256-264 (2016).

140. Debret, B., Andreani, M., Delacour, A., Rouméjon, S. \& Trcera, N. Assessing sulfur redox state and distribution in abyssal serpentinites using XANES spectroscopy. Earth Planet Sci Lett 466, 1-11 (2017).

141. Klein, F. \& Bach, W. Fe-Ni-Co-O-S phase relations in peridotite-seawater interactions. J Petrol 50, 37-59 (2009).

142. Andreani, M. et al. Tectonic structure, lithology, and hydrothermal signature of the Rainbow massif (Mid-Atlantic Ridge 36¹4’N). Geochem Geophys 15, 3543-3571 (2014).

143. McCollom, T. M. \& Bach, W. Thermodynamic constraints on hydrogen generation during serpentinization of ultramafic rocks. Geochim Cosmochim Acta 73, 856-875 (2009).

144. Takai, K. et al. Cell proliferation at $122^{\circ} \mathrm{C}$ and isotopically heavy $\mathrm{CH}_{4}$ production by a hyperthermophilic methanogen under high-pressure cultivation. Proc Natl Acad Sci USA 105, 10949-10954 (2008).

145. Steele, A., McCubbin, F. M. \& Fries, M. D. The provenance, formation, and implications of reduced carbon phases in Martian meteorites. Meteorit Planet Sci 51, 2203-2225 (2016). 